\title{
Structure and bioactivity of the polysaccharides in medicinal plant Dendrobium huoshanense
}

\author{
Yves S.-Y. Hsieh, ${ }^{\mathrm{a}, \dagger}$ Cheng Chien, ${ }^{\mathrm{a}, \mathrm{b}, \dagger}$ Sylvian K.-S. Liao, ${ }^{\mathrm{a}}$ Shih-Fen Liao, ${ }^{\mathrm{a}}$ \\ Wei-Ting Hung, ${ }^{\mathrm{a}}$ Wen-Bin Yang, ${ }^{\mathrm{a}, *}$ Chih-Chien Lin, ${ }^{\mathrm{a}}$ Ting-Jen Rachel Cheng, ${ }^{\mathrm{a}}$ \\ Chia-Chuan Chang, ${ }^{\text {a Jim-Min Fang }}{ }^{\mathrm{a}, \mathrm{b}, *}$ and Chi-Huey Wong ${ }^{\mathrm{a}, *}$ \\ ${ }^{a}$ The Genomics Research Center, Academia Sinica, Taipei 115, Taiwan \\ ${ }^{\mathrm{b}}$ Department of Chemistry, National Taiwan University, Taipei 106, Taiwan \\ Received 11 February 2008; revised 17 April 2008; accepted 19 April 2008 \\ Available online 24 April 2008
}

\begin{abstract}
Detailed structures of the active polysaccharides extracted from the leaf and stem cell walls and mucilage of Dendrobium huoshanense are determined by using various techniques, including chromatographic, spectroscopic, chemical, and enzymatic methods. The mucilage polysaccharide exhibits specific functions in activating murine splenocytes to produce several cytokines including IFN- $\gamma$, IL-10, IL-6, and IL-1 $\alpha$, as well as hematopoietic growth factors GM-CSF and G-CSF. However, the deacetylated mucilage obtained from an alkaline treatment fails to induce cytokine production. The structure and bioactivity of mucilage components are validated by further fractionation. This is the first study that provides clear evidence for the structure and activity relationship of the polysaccharide in $D$. huoshanense.
\end{abstract}

(C) 2008 Elsevier Ltd. All rights reserved.

\section{Introduction}

Dendrobium huoshanense, Orchidaceae, is a precious herbal plant in Chinese traditional medicine. ${ }^{1}$ The sections of the stem were used for the treatment of salivary, stomach, and ophthalmic disorders. It has slow growth rate and excessive harvesting has left it critically endangered in China. Among the species in the polymorphic Dendrobium genus, most studies have focused on small molecules with proved bioactivity, which included the structural types of bibenzyl, phenanthrene, anthracene, fluorene, coumarin, flavone, cinnamate, sesquiterpene, sterol, fatty acid, and alkaloids. ${ }^{2-13}$ In contrast, the polysaccharide constituents were much less investigated, ${ }^{14}$ even though many plant polysaccharides have already shown to trigger immuno-modulatory activities. ${ }^{15-17}$ In this paper, we report the polysaccharide constituents isolated from the leaves and stems of D. huoshanense, and their immuno-modulatory effects in mice splenocytes.

Keywords: Dendrobium huoshanense; Cell wall; Mucilage; Polysaccharide; Structure; Immune response.

* Corresponding authors. Tel.: +886 2 33661663; fax: +8862 23637812 (J.-M.F.), tel.: +886 2 27899400; fax: +886 227898771 (C.-H.W.); e-mail addresses: jmfang@ntu.edu.tw; chwong@gate.sinica.edu.tw

$\dagger$ These authors contributed equally to this work.

\section{Results and discussion}

\subsection{Material and separation procedure}

The plant material of $D$. huoshanense was obtained from Yuen-Foong-Yu Biotech Co., Taiwan. ${ }^{18}$ A flowchart describing the isolation of polysaccharides from cell wall and mucilage of $D$. huoshanense is shown in Figure 1. The tissues containing non-lignified primary cell walls were collected from leaves and stems at $4{ }^{\circ} \mathrm{C}$. The alcoholinsoluble residue (AIR) was treated with porcine pancreatic-amylase to remove starch. The de-starched cell walls were fractionated by a sequence of extraction using CDTA (cyclohexane-1,2-diamine tetraacetate), $\mathrm{Na}_{2} \mathrm{CO}_{3}$, $1 \mathrm{M} \mathrm{KOH}$, and $4 \mathrm{M} \mathrm{KOH}$, as described previously. ${ }^{19}$ The remaining insoluble residue was accounted for the $\alpha$-cellulose fraction. The mucilage polysaccharides collected from leaves and stems did not contain any starch granule as shown by the test with potassium iodide.

\subsection{Monosaccharide composition of cell wall}

The cell-wall AIR preparation and individual fractions were subjected to hydrolysis with trifluoroacetic acid to release monosaccharides, which were subsequently reduced by $\mathrm{NaBH}_{4}$ and acetylated by $\mathrm{Ac}_{2} \mathrm{O}$ to give the corresponding alditol peracetates. The composition of 


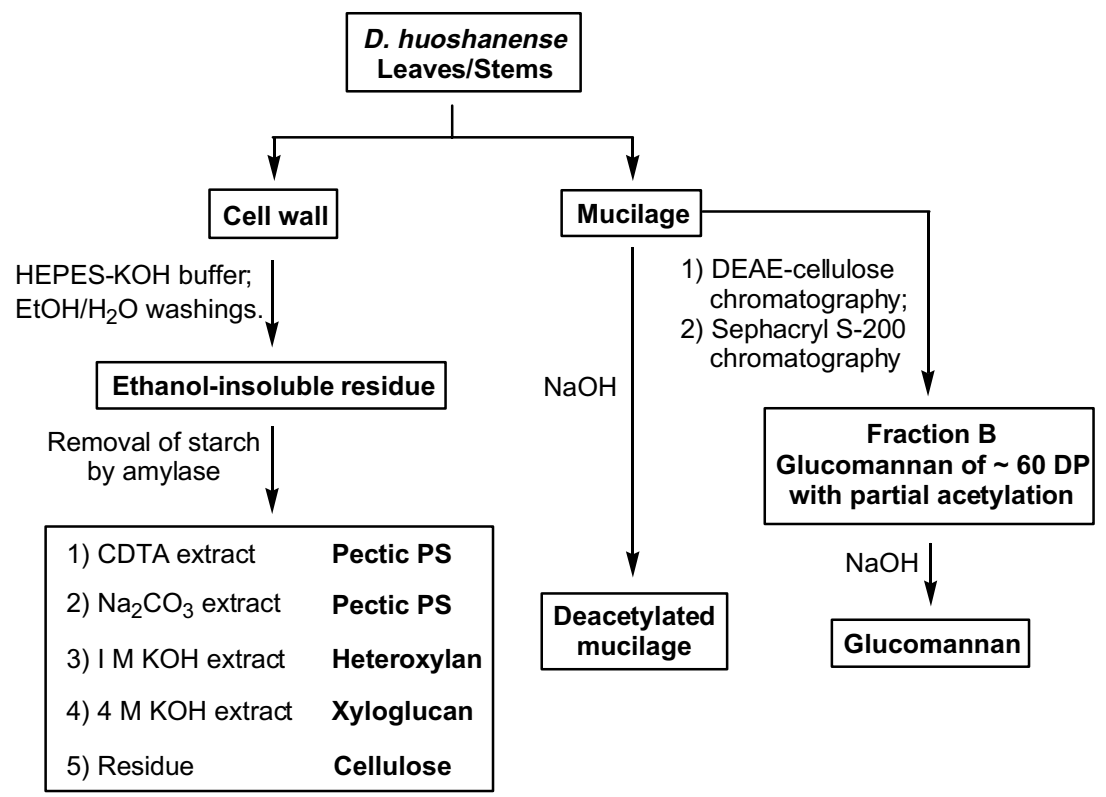

Figure 1. Flowchart describing isolation of polysaccharides from D. huoshanense.

neutral monosaccharides correlated with that of alditol peracetates as determined by the GC-MS analysis (Table 1). The major constituents in the primary non-lignified cell walls of leaves were Ara, Man, Glc, and Gal, with small proportions of Xyl, Rha, and Fuc. On the other hand, the primary cell walls of stems contained mainly Xyl, Glc, Man, and Gal, small proportions of Ara and Rha, and a trace amount of Fuc. It was noted that a greater proportion of $\mathrm{Xyl}$ was found in stem $(28 \mathrm{~mol} \%)$ than in leaf $(7 \mathrm{~mol} \%)$ cell-wall hydrolysates, but smaller proportion of Ara in stem ( $9 \mathrm{~mol} \%)$ than in leaf $(22 \mathrm{~mol} \%)$. The uronic acid contents in the cell-wall preparations of leaves and stems were $11 \mathrm{~mol} \%$ and $4 \mathrm{~mol} \%$, respectively.
Both the CDTA and $\mathrm{Na}_{2} \mathrm{CO}_{3}$ fractions from leaf and stem cell-wall preparations contained large proportions of Man, Gal, and Ara. Much greater amounts of Xyl existed in the $1 \mathrm{M} \mathrm{KOH}$ fractions of leaf $(28 \mathrm{~mol} \%)$ and stem $(65 \mathrm{~mol} \%)$ than in the CDTA and $\mathrm{Na}_{2} \mathrm{CO}_{3}$ fractions. Glucose was the major component in the $4 \mathrm{M}$ $\mathrm{KOH}$ fractions of leaf $(28 \mathrm{~mol} \%)$ and stem (41 mol $\%)$. Three uronic acids were found; galacturonic acid (GalA) predominated in the CDTA and $\mathrm{Na}_{2} \mathrm{CO}_{3}$ fractions, whereas glucuronic acid (GlcA) and 4-O-methyl glucuronic acid (MeGlcA) existed in small amounts. In the 1 and $4 \mathrm{M} \mathrm{KOH}$ fractions of leaves, the content of GlcA was higher than MeGlcA, while the opposite was observed in stems.

Table 1. Composition of neutral monosaccharides and uronic acids in cell walls and individual fractions from the leaves and stems of $D$. huoshanense

\begin{tabular}{|c|c|c|c|c|c|c|c|c|c|c|c|c|}
\hline & \multicolumn{8}{|c|}{ Neutral monosaccharides ${ }^{\mathrm{a}}$} & \multicolumn{4}{|c|}{ Uronic acids $^{\mathrm{a}}$} \\
\hline & $\overline{\mathrm{T}^{\mathrm{b}}}$ & Rha & Fuc & Ara & Xyl & Man & Gal & $\overline{\text { Glc }}$ & $\overline{\mathrm{T}^{\mathrm{b}}}$ & GalA & GlcA & MeGlcA \\
\hline \multicolumn{13}{|l|}{ Leaves } \\
\hline $\mathrm{AIR}^{\mathrm{c}}$ & 89 & 3 & 3 & 22 & 7 & 21 & 13 & 20 & 11 & 10 & $<0.5$ & 1 \\
\hline CDTA $^{\mathrm{d}}$ & 82 & 3 & $<0.5$ & 25 & $<0.5$ & 35 & 13 & 4 & 18 & 18 & $<0.5$ & $<0.5$ \\
\hline $\mathrm{Na}_{2} \mathrm{CO}_{3}{ }^{\mathrm{e}}$ & 91 & $<0.5$ & - & 23 & 6 & 18 & 34 & 10 & 9 & 9 & $<0.5$ & $<0.5$ \\
\hline $1 \mathrm{M} \mathrm{KOH}^{\mathrm{f}}$ & 89 & - & 2 & 17 & 28 & 20 & 9 & 13 & 5 & $<0.5$ & 4 & 1 \\
\hline $4 \mathrm{M} \mathrm{KOH}^{\mathrm{g}}$ & 78 & - & 6 & 5 & 17 & 10 & 12 & 28 & 4 & 1 & 2 & 1 \\
\hline \multicolumn{13}{|l|}{ Stems } \\
\hline AIR & 96 & 1 & $<0.5$ & 9 & 28 & 19 & 11 & 29 & 4 & 3 & $<0.5$ & 1 \\
\hline CDTA & 73 & $<0.5$ & $<0.5$ & 11 & $<0.5$ & 27 & 28 & 5 & 27 & 23 & $<0.5$ & 4 \\
\hline $\mathrm{Na}_{2} \mathrm{CO}_{3}$ & 76 & 1 & $<0.5$ & 27 & 3 & 7 & 31 & 8 & 24 & 23 & $<0.5$ & 1 \\
\hline $1 \mathrm{M} \mathrm{KOH}$ & 94 & - & - & 1 & 65 & $<0.5$ & 19 & 9 & 6 & 2 & $<0.5$ & 4 \\
\hline $4 \mathrm{M} \mathrm{KOH}$ & 94 & - & 2 & 3 & 24 & 14 & 10 & 41 & 6 & 3 & 1 & 2 \\
\hline
\end{tabular}

\footnotetext{
${ }^{\text {a }}$ Composition in $\mathrm{mol} \%$ as average of duplicate determinations.

${ }^{\mathrm{b}}$ Total content in $\mathrm{mol} \%$.

${ }^{\mathrm{c}}$ Alcohol insoluble residue.

${ }^{\mathrm{d}}$ The fraction obtained by extraction with trans-cyclohexane-1,2-diamine-tetraacetate.

${ }^{\mathrm{e}}$ The fraction obtained by extraction with $\mathrm{Na}_{2} \mathrm{CO}_{3}+25 \mathrm{mM} \mathrm{NaBH}$.

${ }^{\mathrm{f}}$ The fraction obtained by extraction with $1 \mathrm{M} \mathrm{KOH}+25 \mathrm{mM} \mathrm{NaBH}_{4}$.

${ }^{\mathrm{g}}$ The fraction obtained by extraction with $4 \mathrm{M} \mathrm{KOH}+25 \mathrm{mM} \mathrm{NaBH}_{4}$.
} 
GalA is characteristic of the presence of pectic polysaccharides, and the presence of both GlcA and 4-O-methyl GlcA is typical in heteroxylans. ${ }^{20}$ Our results indicated that a high proportion of pectic polysaccharides existed in both the CDTA and $\mathrm{Na}_{2} \mathrm{CO}_{3}$ fractions, whereas a large amount of heteroxylan existed in the $\mathrm{KOH}$ fractions.

\subsection{Linkage analysis of the cell-wall fractions}

Glycosyl linkages between monosaccharide residues provided information for the structure of polysaccharides. ${ }^{20}$ The glycosyl linkages of the cell-wall fractions in leaves and stems of $D$. huoshanense are summarized in Table 2. In the CDTA fractions of leaves and stems cell-wall preparations, mannose in the form of 4-Manp and 4,6-Manp was most abundant. Along with the high proportions of t-Gal $f$, 4-Galf, t-Araf, and 5-Araf, the composition of CDTA fractions was characterized by galactomannans, galactans, and arabinans (where ' $t$ ' represents the terminal position of sugars at the non-reducing end). The small amount of 2-Rhap found in the CDTA fractions might be attributed to the presence of rhamnogalacturonans I (RG I). ${ }^{21}$

The glycosyl-linkage compositions in the $\mathrm{Na}_{2} \mathrm{CO}_{3}$ fractions were similar to those in CDTA fractions, albeit with much greater proportions of 4-Galp and smaller proportions of 4-Man $p$ and 4,6-Man $p$. The presence of galactomannans in the pectic fractions $\left(\mathrm{CDTA}+\mathrm{Na}_{2}\right.$ $\mathrm{CO}_{3}$ extractions) of $D$. huoshanense cell-wall prepara- tions is interesting. According to a previous study, ${ }^{22}$ the galactomannan of Leucaena leucocephala can form complexes with divalent metal ions, for example, $\mathrm{Co}^{2+}$, $\mathrm{Mn}^{2+}, \mathrm{Ni}^{2+}$, and $\mathrm{Zn}^{2+}$. It was possible that the leaf and stem cell-wall preparations of $D$. huoshanense might contain the complexes of galactomannan-metal ions, which were subsequently extracted by CDTA and $\mathrm{Na}_{2} \mathrm{CO}_{3}$ treatments.

High proportions of t-Xylp, 4-Xyl $p$, and t-Araf glycosyl linkages were observed in the $1 \mathrm{M} \mathrm{KOH}$ fractions of primary cell-wall preparations of $D$. huoshanense. Along with the presence of GlcA and 4-O-methyl GlcA in high proportions (Table 1), trace amount of glucuronoarabinoxylans (GAXs) was observed. ${ }^{23}$ Unbranched 4-Xylp linkage predominated in the GAXs of $D$. huoshanense. In comparison, the GAXs found in the primary cell walls of maize (Zea mays, Poaceae) and pineapple (Ananas comosus, Bromeliaceae) contain high proportions of branched 2,4-Xylp and 3,4-Xylp glycosyl linkages. ${ }^{24-26}$ Furthermore, the GAXs in D. huoshanense differed from that in grasses and pineapple by having no ester-linked hydroxycinnamic acid. ${ }^{27}$

The presence of xyloglucans in the $\mathrm{KOH}$ fractions of leaves and stems was indicated by the predominant glycosyl linkages of t-Xyl $p, 2-\mathrm{Xyl} p, 4-\mathrm{Glc} p$, and 4,6-Glc $p$ (see Section 2.6). The presence of t-Fuc $p$ indicated that the xyloglucans might be fucosylated. A large amount of 4-Man $p$ glycosyl linkage might be attributable to mannans or glucomannans.

Table 2. Glycosyl-linkage composition in the cell-wall fractions of $D$. huoshanense

\begin{tabular}{|c|c|c|c|c|c|c|c|c|}
\hline \multirow[t]{2}{*}{ Glycosyl linkage } & \multicolumn{4}{|c|}{ Leaves } & \multicolumn{4}{|c|}{ Stems } \\
\hline & CDTA & $\mathrm{Na}_{2} \mathrm{CO}_{3}$ & $1 \mathrm{M} \mathrm{KOH}$ & $4 \mathrm{M} \mathrm{KOH}$ & CDTA & $\mathrm{Na}_{2} \mathrm{CO}_{3}$ & $1 \mathrm{M} \mathrm{KOH}$ & $4 \mathrm{M} \mathrm{KOH}$ \\
\hline 2-Rhap & 2.6 & 1.4 & 0.2 & - & 2.6 & - & - & - \\
\hline t-Fucp & 1.3 & - & 0.1 & 1.4 & - & - & 0.1 & 0.3 \\
\hline $\mathrm{t}-\operatorname{Ara} f$ & 9.3 & 6.7 & 11.3 & 1.4 & 7.1 & 13.1 & 7.4 & 3.5 \\
\hline 2-Araf & 2.3 & 2.1 & 3.9 & - & 2.3 & 2.3 & 1.5 & - \\
\hline 3,5-Araf & 1.9 & 5.9 & - & - & 6.6 & 8.0 & - & - \\
\hline 5-Araf & 5.1 & 5.7 & - & - & 2.8 & 3.2 & - & - \\
\hline $\mathrm{t}-\mathrm{Xyl} p$ & 2.6 & 1.5 & 22.2 & 4.0 & 4.3 & 4.9 & 8.8 & 2.6 \\
\hline 2-Xylp & - & - & 0.5 & 2.6 & - & - & 2.2 & 4.3 \\
\hline 3-Xylp & - & - & 1.6 & 1.8 & - & - & 4.5 & 0.7 \\
\hline 4-Xylp & 1.8 & 2.2 & 14.7 & 11.9 & 0.8 & 1.9 & 30.0 & 13.0 \\
\hline $2,4-\mathrm{Xyl} p$ & - & - & 1.5 & - & - & - & 3.2 & - \\
\hline $3,4-\mathrm{Xyl} p$ & - & 3.2 & 3.2 & 2.0 & - & - & 4.8 & 2.7 \\
\hline $\mathrm{t}-\mathrm{Gal} p$ & 8.2 & 13.5 & 0.9 & 4.0 & 5.4 & 8.5 & 5.7 & 7.3 \\
\hline 4-Galp & 7.0 & 23.5 & 10.7 & 2.2 & 10.1 & 34.4 & 13.4 & 4.1 \\
\hline 6-Galp & 4.5 & 0.7 & - & - & 3.2 & - & - & - \\
\hline 2-Galp & - & - & - & 4.3 & - & - & - & 7.4 \\
\hline $\mathrm{t}-\mathrm{Glc} p$ & 0.6 & 1.6 & 2.8 & 1.2 & 5.2 & 4.2 & 1.6 & 1.9 \\
\hline $2,3-\mathrm{Glc} p$ & 0.5 & - & - & 1.0 & - & - & - & 4.1 \\
\hline 3-Glcp & - & - & - & - & - & - & - & 0.8 \\
\hline $3,4-\mathrm{Glc} p$ & - & - & - & 3.2 & - & - & - & 6.0 \\
\hline 4-Glc $p$ & 7.3 & 7.4 & 6.1 & 39.0 & 7.7 & 7.0 & 6.4 & 18.9 \\
\hline 4,6-Glc $p$ & - & - & 3.3 & 8.4 & - & - & 9.8 & 8.9 \\
\hline 4-Man $p$ & 26.3 & 14.1 & 17.0 & 10.8 & 20.9 & 9.4 & 0.6 & 13.5 \\
\hline 4,6-Man $p$ & 18.7 & 10.5 & - & 0.8 & 21.0 & 3.1 & - & - \\
\hline
\end{tabular}

${ }^{a}$ The polysaccharide sample was subjected to a sequence of permethylation, hydrolysis, reduction, and peracetylation, and the glycosyl linkage was deuced from the GC-MS analysis of the resulting methylated alditol acetates. The data in mole percentage (mol \%) are average of duplicate determinations. 


\subsection{Analysis of the pectic polysaccharides in CDTA fractions}

The above-mentioned analyses of the uronic acid composition and glycosyl linkages indicated the presence of pectic polysaccharides in the CDTA fractions. We further investigated the structure of such pectic polysaccharides by enzymatic digestion and spectral studies. The CDTA fractions of leaf and stem cell-wall preparations were treated with polygalacturonanase to digest the pectins. The mass spectral analysis of the enzymatic digests indicated the presence of oligogalaturonides in 4-15 degrees of polymerization (DP) containing varied degrees of methyl groups. These oligogalaturonides could be derived from homogalacturonans (HGAs), which consisted of the methyl ester of GalA. ${ }^{28}$ The pectins isolated from Angelica auctiloba and Plantogo major were shown to have anti-complement effect. ${ }^{29,30}$ The plants Noni (Morinda citrifolia) and Panax notoginseng, which contain high level of HGA, have medicinal applications. $^{31,32}$ The high content of HGA in the pectin components of $D$. huoshanense might potentially contribute to its bioactivity.

In agreement with the structural deduction, the ${ }^{1} \mathrm{H}$ NMR spectrum $(600 \mathrm{MHz})$ of the polysaccharides in CDTA fractions showed an intense singlet at $\delta 3.7$ for the methyl ester $\left(\mathrm{CO}_{2} \mathrm{CH}_{3}\right)$ and a broad multiplet at $\delta$ 4.3 attributable to the $\mathrm{C}-4$ protons in GalA or its methyl ester. ${ }^{33}$ In the ${ }^{13} \mathrm{C}$ NMR spectrum, the signals for the methyl ester appeared at $\delta 52.7\left(\mathrm{CH}_{3}\right)$ and 170.6 $(\mathrm{C}=\mathrm{O})$, whereas the corresponding carboxyl signal of GalA occurred at $\delta$ 172.6. The ${ }^{1} \mathrm{H}$ NMR spectrum of the pectic polysaccharides also showed a weak signal of doublet at $\delta 1.29$ that might be ascribed as the methyl group in rhamnose, of which the presence was shown by composition and glycosyl-linkage analyses (Tables 1 and 2).

\subsection{Analysis of the heteroxylans in $1 \mathrm{M} \mathrm{KOH}$ fractions}

The $1 \mathrm{M} \mathrm{KOH}$ fraction of leaf cell-wall preparation was hydrolyzed with the enzyme endo- $(1 \rightarrow 4)-\beta$-D-xylanase, and the released oligosaccharides were analyzed by mass spectrometry. The characteristic signals at $m / z 877$, 1009,1141 , and 1273 correlated with the $[\mathrm{M}+\mathrm{Na}]^{+}$ions of Pen $_{5}$ GlcA, Pen 6 GlcA, Pen ${ }_{7}$ GlcA, and Pen 8 GlcA, whereas the signals at $\mathrm{m} / z 1023$ and 1155 were attributed to the $[\mathrm{M}+\mathrm{Na}]^{+}$ions of Pen $_{6} \mathrm{MeGlcA}$ and $\mathrm{Pen}_{7} \mathrm{MeGlcA}$ (where Pen represents pentoside). These results were consistent with the high contents of GlcA and MeGlcA observed in the uronic acid analysis (Table 1). Similarly, enzymatic digestion and $\mathrm{MS}$ analysis of the $1 \mathrm{M} \mathrm{KOH}$ fraction of stem cell-wall preparation indicated the presence of the pentose oligomers of Pen $x_{x}$ GlcA $(x=5-9)$, Pen $_{y}$ MeGlcA $(y=4-9)$, and $\operatorname{Pen}_{z}(\mathrm{MeGlcA})_{2} \quad(z=5-$ 11). The pentose oligomers with substitution of (MeG$\mathrm{lcA})_{2}$ disaccharide were found in stems only, but not in leaves.

We also confirmed the presence of L-arabinose at the terminal of the oligosaccharides by treatment with $\alpha-\mathrm{L}-$ arabinosidase. After the enzymatic removal of arabino- syl residues, the overall mass profile for the GlcA- and MeGlcA-substituted pentose oligomers did not change, albeit all the $[\mathrm{M}+\mathrm{Na}]^{+}$ions showed a reduction of $132 \mathrm{Da}$ in comparison with the original mass signals for the sample without $\alpha$-L-arabinosidase treatment. This experiment clearly indicated the presence of mono-substituted arabinosyl residue at the terminal, a characteristic of glucuronoarabinoxylans (GAXs).

\subsection{Analysis of the xyloglucans in $4 \mathrm{M} \mathrm{KOH}$ fraction}

The $4 \mathrm{M} \mathrm{KOH}$ fraction of leaf cell-wall preparation was subject to enzymatic degradation by endo-( $1 \rightarrow 4)-\beta-\mathrm{D}-$ glucanase. The hydrolysate was analyzed by high $\mathrm{pH}$ anion-exchange chromatography-pulsed amperometric detection (HPAEC-PAD) and MALDI-TOF MS (Fig. 2) to show the presence of xyloglucans (XGs). ${ }^{34}$ The $[\mathrm{M}+\mathrm{Na}]^{+}$ions in the MS spectrum corresponded to XXG $(m / z$ 791), XXGG ( $m / z$ 953), XXXG $(m / z 1085)$, XLXG/XXLG $(m / z 1247)$, XXFG $(m / z ~ 1393)$, XLLG $(\mathrm{m} / z$ 1409), and XLFG $(\mathrm{m} / \mathrm{z} 1555)$, where $\mathrm{G}$ represents the backbone Glc in $\beta 1,4$-linkage, $X$ represents the $X y-$ $1(\alpha 1,6)$ Glc unit, L represents $\operatorname{Gal}(\beta 1,2) \mathrm{Xyl}(\alpha 1,6) \mathrm{Glc}$, and $F$ represents $\operatorname{Fuc}(\alpha 1,2) \operatorname{Gal}(\beta 1,2) \operatorname{Xyl}(\alpha 1,6)$ Glc. $^{35}$ The similar composition of XGs was found in the stem cell-wall preparation of $D$. huoshanense. Our results showed that the XGs of $D$. huoshanense have both XXGG and XXXG backbones with fucosylated XG oligosaccharides XXFG and XLFG. XGs with terminal Fuc and Gal side chain have been shown to induce anti-tumor activity in cell-based assays. ${ }^{36}$

\subsection{Analysis of the polysaccharides in stem mucilage}

The presence of glucomannan was confirmed by using glucomannan assay kit (Megazyme, see Section 3.1). The de-starched mucilage polysaccharide hydrolysate was found to contain Man (79\%) and Glc (21\%) as deduced from the corresponding alditol acetates in the GC-MS analyses. Accordingly, the mass spectrum of endo-( $1 \rightarrow 4)-\beta$-D-mannanase hydrolysate of the mucilage polysaccharide gave the molecular ions attributable to glucomanno-oligosaccharides of 3-9 DP with partial acetylation.

In agreement with the structural assignments of $\beta$ $(1 \rightarrow 4)-D-G l c p$ and $\beta-(1 \rightarrow 4)-D-M a n p$, their anomeric carbons appeared at $\delta 102.8$ (minor component) and 100.6 (major component), respectively. ${ }^{37}$ The degree of acetylated mannose was estimated to be $25 \%$. In addition to the signals at $\delta_{\mathrm{H}} 2.20 / \delta_{\mathrm{C}} 20.3$ and $\delta_{\mathrm{C}} 173.5$ for the acetyl group of 2 - $O$-acetyl- $\beta$ - $(1 \rightarrow 4)$-D-mannose, the minor signals $(\sim 5 \%)$ occurring at $\delta_{\mathrm{H}} 2.05 / \delta_{\mathrm{C}} 20.5$ and $\delta_{\mathrm{C}} 174.0$ might be attributable to 3- $O$-acetyl- $\beta$ $(1 \rightarrow 4)$-D-mannose. Moreover, the mucilage polysaccharide was subject to alkaline treatment to remove acetyl groups. After dialysis, the heteronuclear single quantum coherence (HSQC) spectrum of the deacetylated polysaccharide was recorded, and the ${ }^{1} \mathrm{H}-{ }^{13} \mathrm{C}$ signals were assigned according to the literature. ${ }^{38}$ The HSQC spectrum clearly indicated that the deacetylated mucilage polysaccharide was composed of $(\beta 1 \rightarrow 4)$ linked D-Man $p$ and $(\beta 1 \rightarrow 4)$-linked D-Glc $p$ (Fig. 3). ${ }^{37}$ 

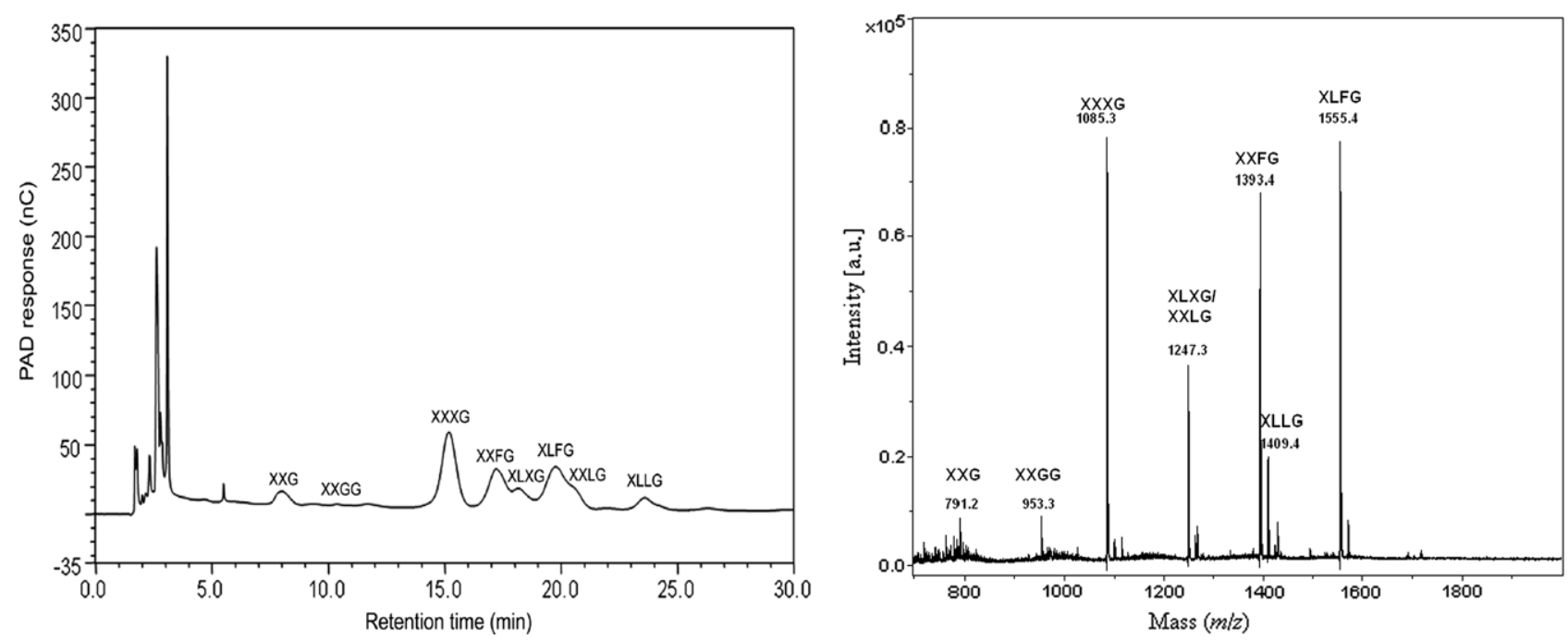

Figure 2. HPAEC-PAD chromatogram (left panel) and MALDI-TOF MS spectrum (right panel) of XG oligosaccharides released from the 4 M $\mathrm{KOH}$ fraction of $D$. huoshanense leaf cell-wall preparation with treatment of endo-( $\rightarrow 4)-\beta$-D-glucanase. The peak assignment was based on the retention times of the XG oligosaccharide standards. G, Glc; X, Xyl-Glc; L, Gal-Xyl-Glc; F, Fuc-Gal-Xyl-Glc.

\subsection{Bioactivities of the polysaccharides and the deacet- ylated polysaccharides from mucilage preparations}

Dendrobium huoshanense has been reported as one of the best Chinese medicines used for cell growth and immuno-modulatory activities; however, with only little scientific evidence. We first used the MTS assay to determine the cell proliferation effects of the polysaccharide fractions from the different $D$. huoshanense structures. As shown in Table 3, mice splenocytes incubated with mucilage fractions significantly grew faster than untreated cells $(154 \%$ for stem mucilage and $141 \%$ for leaf mucilage vs $100 \%$ for control cells). The effects are more obvious compared with the glucomannan from konjac. Both ivory nut mannan (15-80 DP) and mannose $\beta$ $(1 \rightarrow 4)$-linked oligosaccharide $(15 \mathrm{DP})$ were used for the cellular experiments, but no apparent bioactivity was observed. The cytokine profiling of Dendrobium mucilage indicated an increased expression of several cytokines including IFN- $\gamma$, IL-10, IL-6, and IL- $1 \alpha$. Significant amounts of hematopoietic growth factors GMCSF and G-CSF were also induced. ${ }^{39}$ We further examined the dose-dependent effects of the stem mucilage polysaccharide on the G-CSF and GM-CSF induction. The stimulatory effects on the production of both factors were dose-dependent, up to $250 \mu \mathrm{g} / \mathrm{mL}$ (Fig. 4).

Most interestingly, we investigated whether structural modification of stem mucilage polysaccharide by deacetylation of 2-O-acetylglucomannan would affect its stimulatory effect on cytokine production. Treatment of cells with the deacetylated stem mucilage polysaccharide was

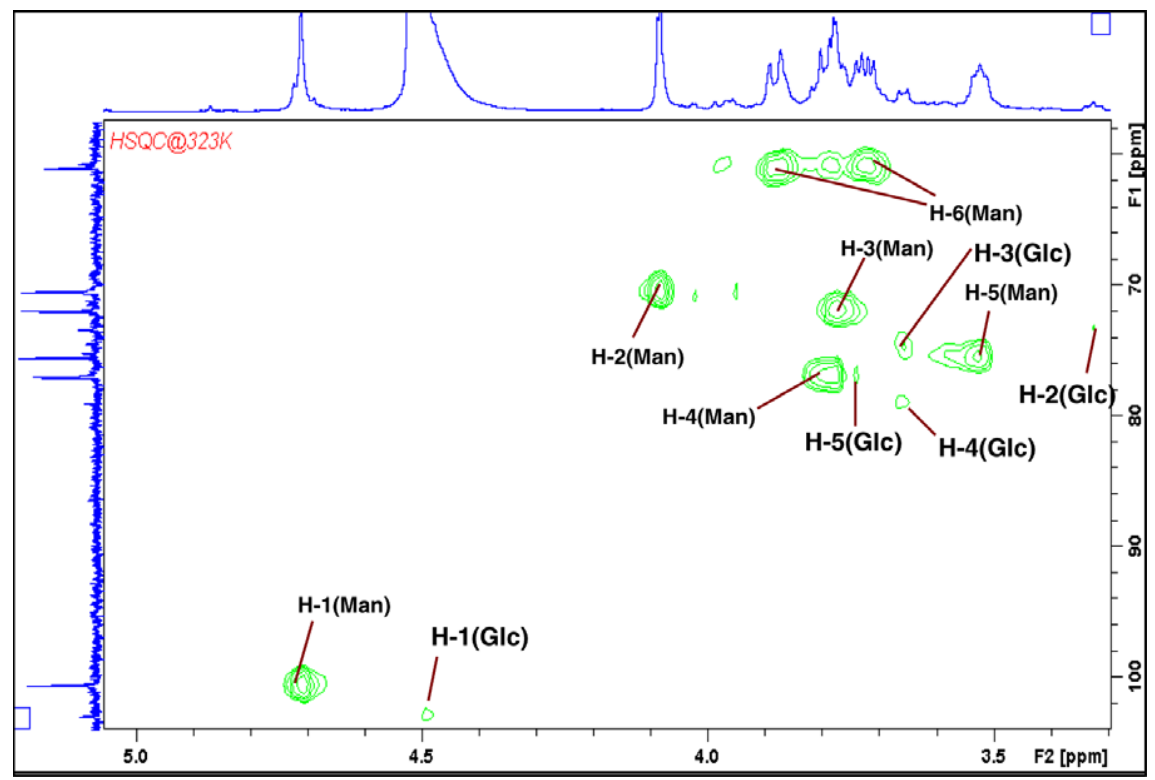

Figure 3. HSQC spectrum of the deacetylation product from the glucomannan of stem mucilage. 
Table 3. Cell proliferation and cytokines induced by different polysaccharide fractions from $D$. huoshanense

\begin{tabular}{|c|c|c|c|c|c|c|c|}
\hline & \multirow[t]{2}{*}{ Cell proliferation $(\%)^{\mathrm{a}}$} & \multicolumn{6}{|c|}{ Cytokine quantitation $(\mathrm{pg} / \mathrm{mL})^{\mathrm{b}}$} \\
\hline & & GM-CSF & G-CSF & IFN- $\gamma$ & IL-10 & IL- $1 \alpha$ & IL-6 \\
\hline Untreated cells & 100 & $<50$ & $<50$ & $<50$ & $<50$ & $<50$ & $<50$ \\
\hline Con A & $155 \pm 5$ & $408 \pm 58$ & $46 \pm 9$ & $1504 \pm 387$ & $590 \pm 75$ & $79 \pm 42$ & $511 \pm 20$ \\
\hline Glucomannan $^{\mathrm{c}}$ & $106 \pm 2$ & $\mathrm{NA}^{\mathrm{e}}$ & $\mathrm{NA}^{\mathrm{e}}$ & $<50$ & $<50$ & $117 \pm 8$ & $<50$ \\
\hline Mannan $^{\mathrm{d}}$ & $106 \pm 2$ & $\mathrm{NA}^{\mathrm{e}}$ & $\mathrm{NA}^{\mathrm{e}}$ & $<50$ & $<50$ & $92 \pm 8$ & $<50$ \\
\hline Leave mucilage & $141 \pm 2$ & $95 \pm 17$ & $582 \pm 56$ & $1563 \pm 424$ & $241 \pm 9$ & $322 \pm 48$ & $451 \pm 23$ \\
\hline Stem mucilage & $154 \pm 4$ & $118 \pm 18$ & $660 \pm 58$ & $1465 \pm 447$ & $286 \pm 30$ & $260 \pm 91$ & $476 \pm 17$ \\
\hline Deacetyl-mucilage & $100 \pm 1$ & $<50$ & $<50$ & $<50$ & $<50$ & $<50$ & $<50$ \\
\hline
\end{tabular}

${ }^{a}$ Mice splenocytes $\left(5 \times 10^{5}\right)$ were incubated with $50 \mu \mathrm{g} / \mathrm{mL}$ of different polysaccharide fractions for $60 \mathrm{~h}$, and then subjected to MTS assay as described in Section 3.1. The OD at $492 \mathrm{~nm}$ of individual samples was normalized against the $\mathrm{OD}_{492}$ of the untreated cells, which were defined as $100 \%$ cell proliferation.

${ }^{\mathrm{b}}$ After cells were incubated with $50 \mu \mathrm{g} / \mathrm{mL}$ of indicated preparations for $48 \mathrm{~h}$, the culture medium was harvested and the cytokine production was analyzed using Quantikine mouse ELISA kits.

${ }^{\mathrm{c}}$ Glucomannan from konjac.

${ }^{\mathrm{d}}$ Mannan from ivory nut (15-80 DP).

${ }^{\mathrm{e}}$ Not available.
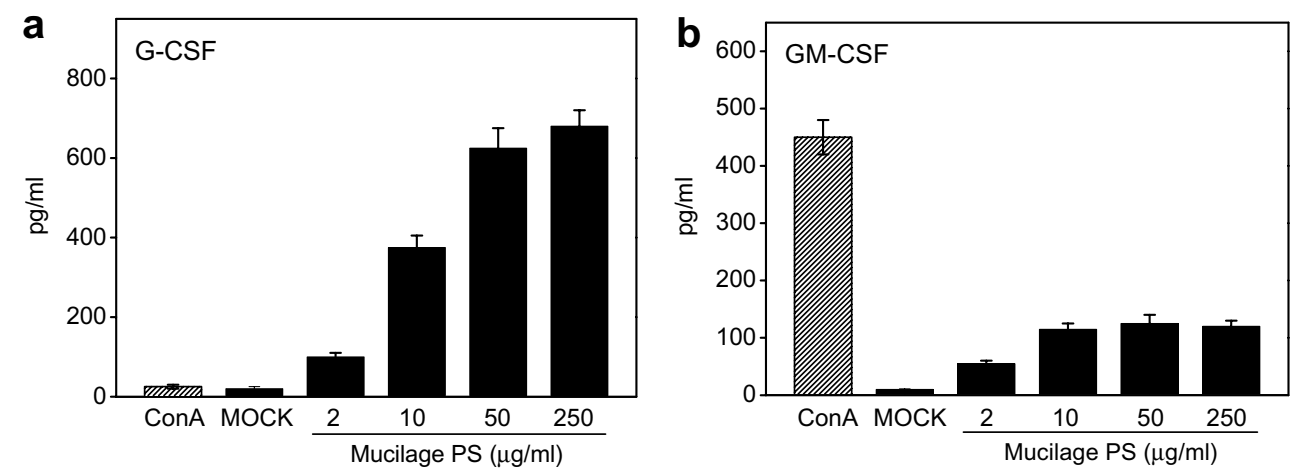

Figure 4. The dose-response relationship of mucilage polysaccharide on the production of cytokines and hematopoietic growth factors. Mice splenocytes $\left(5 \times 10^{6}\right.$ cells $)$ were stimulated with Con A $(2 \mu \mathrm{g} / \mathrm{mL})$ or stem mucilage polysaccharide $(2-250 \mu \mathrm{g} / \mathrm{mL})$. After $48 \mathrm{~h}$ incubation, cell culture supernatant was harvested and analyzed for (a) G-CSF and (b) GM-CSF production using the ELISA kits.

found to maintain cell proliferation, but fail to induce cytokine production (Table 3).

\subsection{Validation of structure and bioactivity via fraction- ation of mucilage components}

The extract of mucilage was fractionated by anion-exchange chromatography on DEAE-cellulose $\left(\mathrm{NH}_{2}{ }^{-}\right.$ form) column. Elution with distilled water afforded neutral polysaccharides, and the subsequent elution with aqueous $\mathrm{NaCl}$ buffer gave the uronic and aldonic acid containing polysaccharides. Six fractions were obtained, and each fraction was subject to dialysis (molecular-weight cutoff $=500$ ) to remove salt. The most potent fraction (6\% of weight) in cytokines expression was further separated by size-exclusion chromatography on Sephacryl S-200 into fractions A $(31 \%), \mathrm{B}(13 \%), \mathrm{C}(18 \%), \mathrm{D}(17 \%), \mathrm{E}(8 \%)$, and $\mathrm{F}$ $(13 \%)$. The cytokines expressions of these polysaccharide fractions were measured by the RT-PCR analyses (Fig. 5). Though G-CSF was not induced by Con A (lane 2), the cytokine expression on treatment with the polysaccharides from mucilage (lane 3 ) and fractions B-F (lanes 5-9) were confirmed. Fraction $\mathrm{C}$ is more active than fraction $\mathrm{B}$ for IL-6, G-CSF, and

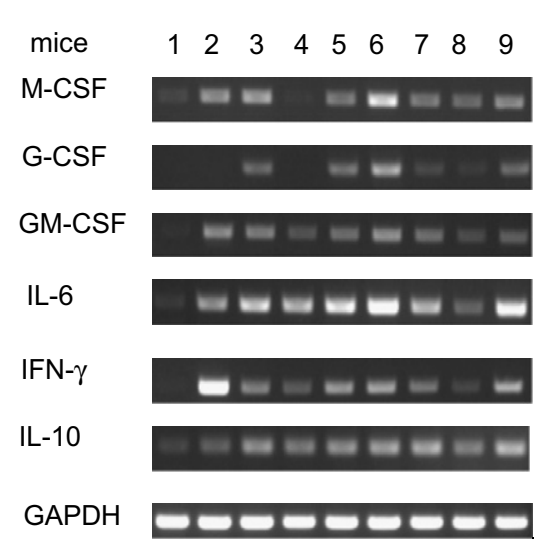

Figure 5. Assessment of cytokines (G-CSF, IL-10, IFN- $\gamma$, IL-6, GMCSF, and M-CSF) by RT-PCR on treatment of mouse splenocytes with different drugs for $12 \mathrm{~h}$. Lane 1, untreatment; lane 2, Con A (4 $\mu \mathrm{g} /$ $\mathrm{mL})$; lane 3 , crude extract of $D$. huoshanense mucilage $(100 \mu \mathrm{g} / \mathrm{mL})$; lane 4, fraction A $(100 \mu \mathrm{g} / \mathrm{mL})$; lane 5, fraction B $(100 \mu \mathrm{g} / \mathrm{mL})$; lane 6 , fraction $\mathrm{C}(100 \mu \mathrm{g} / \mathrm{mL})$; lane 7 , fraction $\mathrm{D}(100 \mu \mathrm{g} / \mathrm{mL})$; lane 8 , fraction $\mathrm{E}(100 \mu \mathrm{g} / \mathrm{mL})$; and lane 9 , fraction F $(100 \mu \mathrm{g} / \mathrm{mL})$. Glyceraldehyde-3phosphate dehydrogenase (GAPDH) is used as an internal control.

M-CSF, but fraction B is good for IL-6 (a B-cell stimulatory factor). 
The composition and structure for the polysaccharide of fraction B were rigorously determined by a combination of chemical, enzymatic, and spectroscopic methods. The polysaccharide of fraction B was subject to hydrolysis with trifluoroacetic acid to release the monosaccharide components, which were subsequently reduced by $\mathrm{NaBH}_{4}$ and acetylated by $\mathrm{Ac}_{2} \mathrm{O}$ to give the corresponding alditol peracetates. The GC-MS analysis of such alditol peracetates correlated to the polysaccharide of fraction B with the composition of mannose and glucose in a ratio of 10:1. On the other hand, the polysaccharide of fraction B was subjected to methylation, acid-catalyzed hydrolysis, reduction and acetylation to give the corresponding methylated alditol peracetates, which was determined by GC-MS analysis to reveal the glycosyl linkages. By this method, the polysaccharide of fraction $\mathrm{B}$ was deduced to have a backbone consisting of $(1 \rightarrow 4)$-linked Man $p$ and Glcp.

The degree of acetylation in the polysaccharide of fraction B was determined by the NMR analysis (Fig. 6). The NMR spectrum showed the characteristic anomeric protons (H-1) for unacetylated mannopyranoside (Man), 2-O-AcMan $p \quad\left(\operatorname{Man}_{24}\right)$, and 3-O-AcMan $p$ $\left(\mathrm{Man}_{34}\right)$ at $\delta$ 4.64-4.74, 4.93-4.82, and 4.74-4.81, respectively, in a ratio of $66: 19: 15$ deduced from the integration of individual Man $p$ signals in the polysaccharide of fraction $\mathrm{B}$.

High performance size-exclusion chromatography (HPSEC) coupled with RI and UV detection was used to estimate the homogeneity and molecular weight of the polysaccharide in fraction $\mathrm{B}$. The retention times on two different HPLC columns (Thermo BioBasic SEC-1000 and TSK-GEL G3000 columns) were measured (Fig. 7), and the molecular weight of the dominant component was estimated to be $\sim 10 \mathrm{kDa}$ by calibration with pullulan standards.

In an alternative approach, diffusion-ordered NMR spectroscopy (DOSY) experiment was used to evaluate the molecular weights of linear and slightly branched water soluble uncharged polysaccharides. ${ }^{40-42}$ The relationship between the molecular weight (MW) of polysaccharide and self-diffusion coefficient $(D)$ is shown in the following equation:

$$
D=8.2 \times 10^{-9} \mathrm{MW}^{-0.50}\left(\mathrm{~m}^{2} \mathrm{~s}^{-1}\right)
$$

The calibration curve of pullulan standards is established to give an exponent value of 0.50 , which is generally applied to other neutral polysaccharide systems. ${ }^{40}$ As to fraction B, the measured $D$ value of -10.08 corresponded to an average molecular weight of $9.7 \mathrm{kDa}$ (Fig. 8), in agreement with that deduced from the HPSEC analysis. Thus, fraction B was attributable to a glucomannan polysaccharide of $\sim 60 \mathrm{DP}$ with partial acetylation.

Nuclear Overhauser enhancement (NOE), which depends on the interplay of proximal protons, provides valuable information for assessment of molecular con-

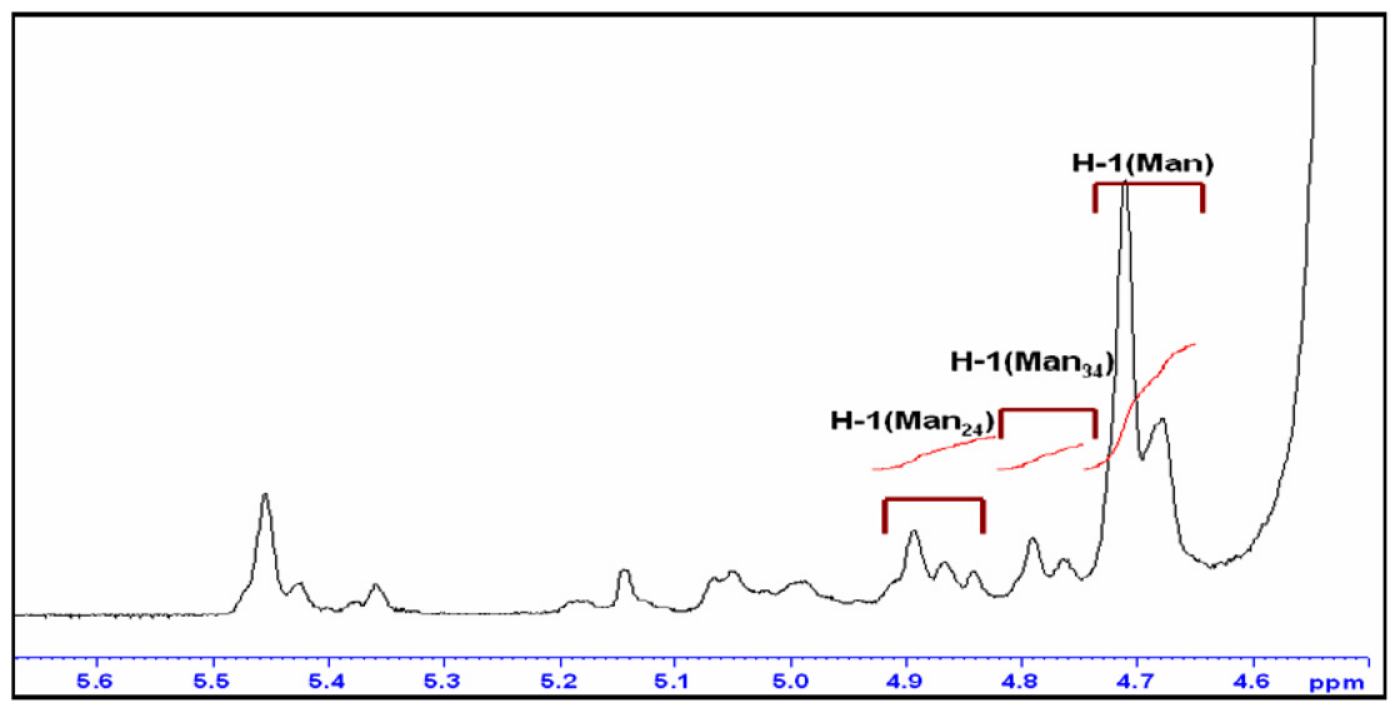

Figure 6. ${ }^{1} \mathrm{H}$ NMR spectrum of the polysaccharide of fraction $\mathrm{B}$ in $\mathrm{D}_{2} \mathrm{O}$ shows the ratio of Manp/2-O-AcManp/3-O-AcMan $p=66: 19: 15$.

a

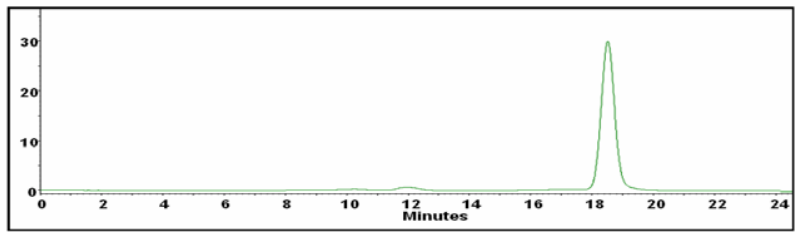

b

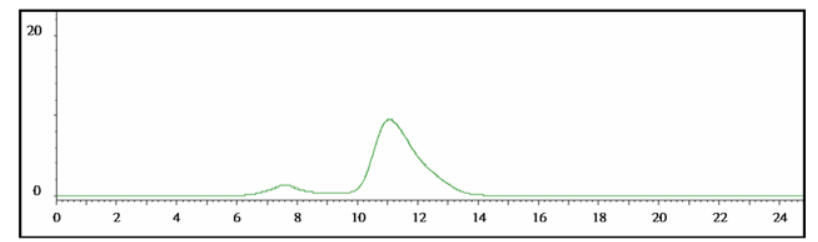

Figure 7. Refractive-index profile of HPSEC analysis of the polysaccharides in fraction B on the SEC-1000 column (a) and G-3000 column (b). 


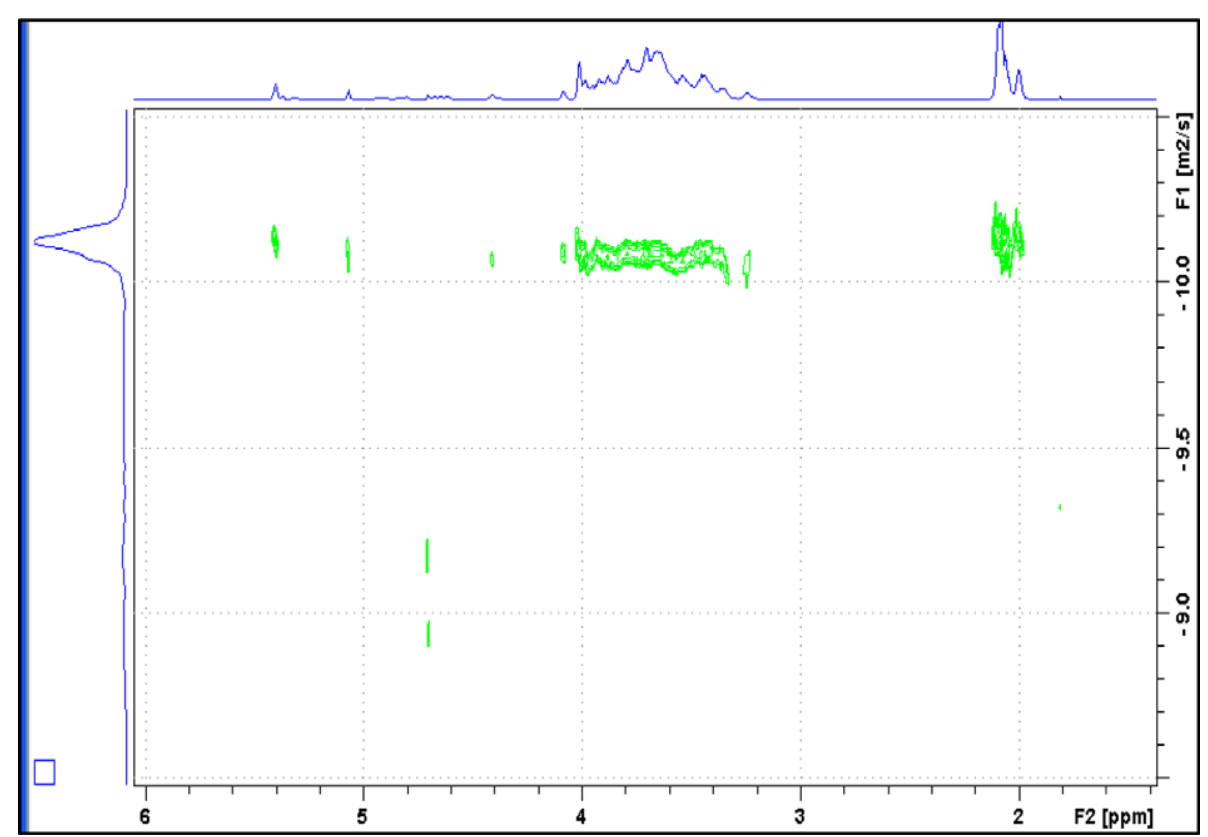

Figure 8. DOSY spectroscopy of fraction B. The molecular weight of $9.7 \mathrm{kDa}$ was deduced from the equation $D=8.2 \times 10^{-9} \mathrm{MW}^{-0.50}\left(\mathrm{~m}^{2} \mathrm{~s}^{-1}\right)$ with the diffusion coefficient of -10.08 .

formation and proton assignment. In general, intramolecular NOE signals were observed in the proton pair having disposition of 1,3-diaxial or vicinal equatorialaxial relationship in a pyranosyl ring. Thus, the anomeric proton (H-1) in $\beta$-D-mannoside would exert NOEs to $\mathrm{H}-2, \mathrm{H}-3$, and $\mathrm{H}-5,{ }^{43}$ whereas $\alpha$-D-mannoside would show only a strong NOE between H-1 and H-2. Accordingly, the polysaccharide of fraction $\mathrm{B}$ was determined to contain the mannosides with $\beta$-linked configuration. Thus, the H-1 resonance of unacetylated mannopyranosyl residues, which were linked to either mannopyrano- syl or glucopyranosyl residues, was selected for irradiation to give the differential NOE spectrum (Fig. 9). The intra-residue NOEs with the H-2, H-3, and $\mathrm{H}-$ 5 in mannopyranoside and the inter-residue NOE with the H-3 in glucopyranoside were observed. This result was in agreement with the $\beta$-linked configuration of mannosides in the glucomannan.

The acetyl groups in the polysaccharide of fraction B were removed by alkaline treatment. The de-esterified glucomannan was then subject to enzymatic digestion

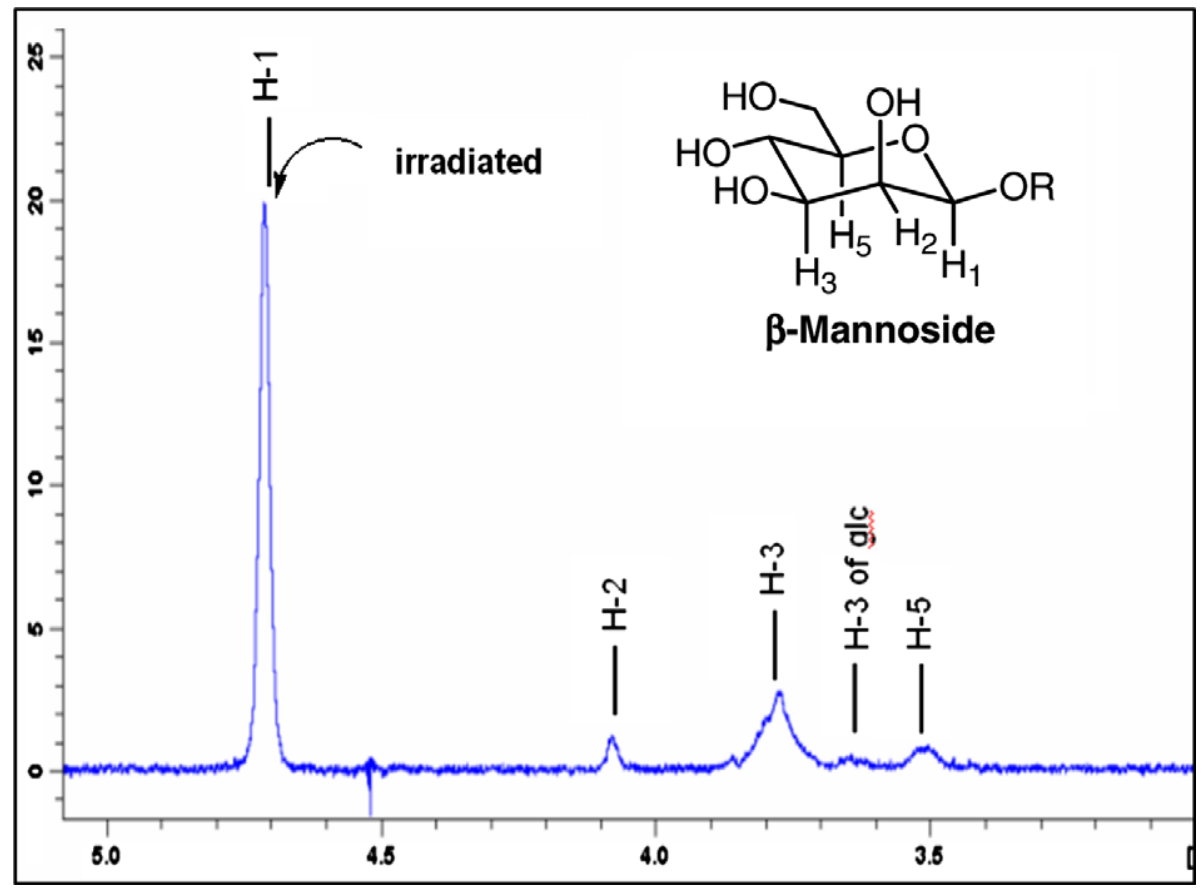

Figure 9. The differential NOE spectrum of fraction B shows the mannoside units in the $\beta$-glycosidic linkage. 
to determine the glycosidic linkages. After digestion with endo- $\beta$-mannase or $\beta$-mannosidase, the hydrolysate was found to contain significant amounts of mannose and oligomannosides in a series, by comparison with the standards on HPAEC-PAD analyses. In contrast, no free mannose was released by treatment of the decetylated glucomannan with $\alpha$-mannosidase. These enzyme assays thus confirmed the $\beta$ linkage of mannosides in the polysaccharide of fraction $\mathrm{B}$.

The 2D-NMR spectra further provided information for the structural assignment. Due to the deshielding effect of acetyl group, three sets of $\mathrm{H}-2$ in 2-O-acetylated $\beta$ Man $p$ units occurred at $\delta 5.45,5.42$, and 5.36, whereas two sets of H-2 in 3-O-acetylated $\beta$-Man $p$ units appeared at $\delta 5.05$ and 4.99 . Correlations of the protons with carbon signals were found by correlation spectroscopy (COSY), total correlation spectroscopy (TOCSY), HSQC, heteronuclear multiple bond correlation (HMBC), and rotating-frame Overhauser effect spectra (REOSY). The anomeric proton and carbon at the reducing end of $\alpha-\operatorname{Man} p$ residue was readily identified at $\delta_{\mathrm{H}} 5.14$ and $\delta_{\mathrm{C}} 94.4$ in the HSQC spectrum of fraction B. The $(1 \rightarrow 4)$-linked $\beta$-Glc residue was characterized by the cross-peak between $\delta_{\mathrm{H}} 4.48$ and $\delta_{\mathrm{C}} 102.8$ in the HSQC spectrum.

In addition to the intra-glycosidic correlations of proton and carbon signals, the HMBC spectrum (Fig. 10) revealed the inter-residue cross-peaks of the anomeric proton $(\mathrm{H}-1)$ with the $\mathrm{C}-4$ of the adjacent saccharide unit via the ${ }^{3} J$-coupling. Thus, the HMBC spectrum manifested the existence of the disaccharide units ManGlc, ManMan, ManMan $34, \operatorname{Man}_{24} \mathbf{M a n}_{24}, \operatorname{Man}_{24} \mathbf{M a n}_{34}$, $\operatorname{Man}_{34} \mathrm{Man}$, and GlcMan.

In the ROESY spectrum (Fig. 11), the anomeric proton $(\mathrm{H}-1)$ of acetylated $\beta$-Man $p$ displayed three intra-residue cross-peaks, ${ }^{44,45}$ namely $\mathrm{H}-1 / \mathrm{H}-2, \mathrm{H}-1 / \mathrm{H}-3$, and $\mathrm{H}-1 / \mathrm{H}-$ 5 due to their short spatial distances similar to those found in the NOE spectrum (Fig. 9). In addition, the sequential inter-residue correlations, such as ' $\mathrm{H}-1$ (Man)$/ \mathrm{H}-3\left(\mathrm{Man}_{34}\right)^{\prime} \quad\left(\delta\right.$ 4.68/5.05) and 'H-1( $\left.\mathrm{Man}_{24}\right) / \mathrm{H}-3$ $\left(\operatorname{Man}_{34}\right)^{\prime}(\delta 4.84 / 4.99)$, also indicated a great population of the fragments $\mathrm{ManMan}_{34}$ and $\mathrm{Man}_{24} \mathrm{Man}_{34}$.

On the basis of the afore-mentioned 1D- and 2D-NMR spectral studies and by analogy to the previous relevant reports, ${ }^{44,45}$ the ${ }^{1} \mathrm{H}$ and ${ }^{13} \mathrm{C}$ NMR spectral data of the polysaccharide in fraction $\mathrm{B}$ are summarized in Table 4. A partial structure for the acetyl-glucomannan is tentatively depicted in Figure 12 to account for the ratio of glucoside to mannoside $(\sim 1: 10)$ and the degree of acetylation $(\sim 35 \%)$.

\subsection{Conclusion}

Our study indicates that the polysaccharides in the cell wall and stem of $D$. huoshanense are mainly composed of monosaccharides Xyl, Ara, Man, Glc, Gal, and GalA, along with small proportions of Rha, Fuc, GlcA, and 4-O-methyl GalA. The glycosyl linkages of these monosaccharide residues were determined to give an insight into the structure of polysaccharides. The pectic fractions from the CDTA extraction of the cell wall and stem polysaccharides were found to contain galactomannans, galactans, arabinans, and rhamnogalacturonans I, whereas heteroxylan, glucuronoarabinoxylans, and xyloglucans existed in the $\mathrm{KOH}$ fractions. Some xyloglucans are modified with terminal fucose and Gal side chain. The stem mucilage contains glucomannan in $\beta$-( $1 \rightarrow 4)$-D-Glc $p$ and $\beta$ - $(1 \rightarrow 4)$-DMan $p$ linkages with partial acetylated mannosides at the 2- and 3-position. Our study showed that the mucilage polysaccharide exhibited specific functions in murine splenocytes. The mucilage induced several cytokines, including IFN- $\gamma$, IL-10, IL-6, and IL- $1 \alpha$, and hematopoietic growth factors GM-CSF and GCSF. However, the deacetylated mucilage obtained from an alkaline treatment failed to induce cytokine production.

The extract of mucilage was further fractionated by chromatography on anion-exchange DEAE-cellulose and Sephacryl size-exclusion columns. The bioactive polysaccharide fraction $\mathrm{B}$ was determined to have an average molecular weight of $\sim 10 \mathrm{kDa}$, and its composition and structure were rigorously determined by a combination of chemical, enzymatic, and spectroscopic methods. This is the first study that provides clear evidence for the structure and activity relationship of the polysaccharide in $D$. huoshanense.

\section{Experimental}

\subsection{Materials}

Dendrobium huoshanense cultivar YFY-HS1 (US Patent No. PP16,746) was obtained from Yuen-Foong-Yu Biotech Co., Ltd, Taiwan. Tamarind XG oligosaccharide standards, the konjac glucomannan, the ivory nut mannan, the polygalacturonanase from Aspergillus niger (EC 3.2.1.15), endo-( $\rightarrow 4)-\beta$-D-xylanase from rumen microorganism (EC 3.2.1.8), endo-(1 $\rightarrow 4)-\beta$-Dmannanase from $A$. niger (EC 3.2.1.78), endo-( $\rightarrow 4)$ $\beta$-D-glucanase from Trichoderma $s p$. (EC 3.2.1.4), and $\alpha$-L-arabinosidase from $A$. niger (EC 3.2.1.55), and glucomannan assay kit were purchased from Megazyme International Ireland Ltd (Wicklow, Ireland). ${ }^{46}$ Pancreatic-amylase (EC 3.2.1.1) was purchased from SigmaAldrich (St. Louis, MO 63103, USA). XG standards the XXG, XXGG, XXFG, and XLFG were kindly gift from Dr. Philip J. Harris (University of Auckland, NZ). Concanavalin A (Con A, C5275) from Canavalia ensiformis (Jack bean) and Lipopolysaccharide (LPS, L6529) were obtained from Sigma Chemical Co. (Sigma, St. Louis, MO). Complete medium for culture of splenocytes was RPMI 1640 (Gibco, Grand Island, NY) supplemented with 10\% FCS (Hyclone, Logan, UT), $0.05 \mathrm{mM}$ 2-mercaptoethanol, and $1 \%$ penicillinstreptomycin (Sigma). Sephacryl S-200 was purchased from GE Healthcare, DEAE-cellulose was purchased from Sigma-Aldrich, and dialysis membrane was purchased from SPECTRUM. 

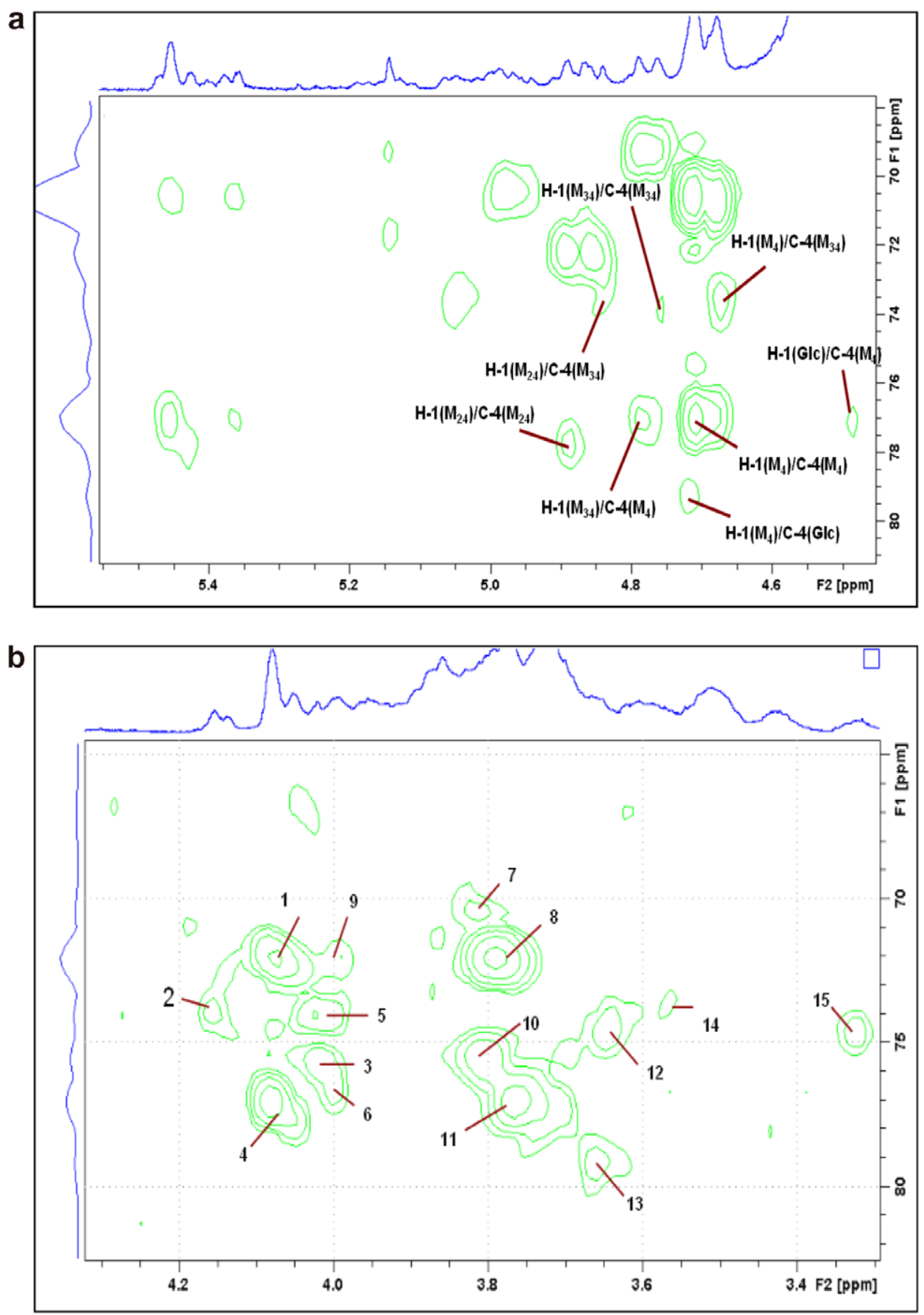

Figure 10. HMBC spectrum of fraction B. (a) The cross-peaks in the region of $\delta 5.55-4.45$, and (b) the cross-peaks in the region of $\delta 4.30-3.30$. Cross-peaks 1, H-2(Man)/C-3(Man); 2, H-2(Man $\left.{ }_{34}\right) / C-3\left(\operatorname{Man}_{34}\right) ; 3$, H-4(Man $\left.{ }_{34}\right) / C-5\left(\operatorname{Man}_{34}\right) ; 4$, H-2(Man)/C-4(Man); 5, H-4(Man $\left.{ }_{34}\right) / C-3\left(M_{34}\right) ; 6$,

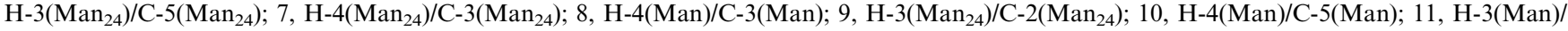
C-4(Man); 12, H-4(Glc)/C-3(Glc); 13, H-3(Glc)/C-4(Glc); 14, H-5(Man $\left.{ }_{34}\right) / \mathrm{C}-4\left(\mathrm{Man}_{34}\right) ; 15, \mathrm{H}-2(\mathrm{Glc}) / \mathrm{C}-3(\mathrm{Glc})$. All the saccharides were linked in the backbone by $\beta$ - $(1 \rightarrow 4)$ linkage. $\mathrm{Man}_{24}$ represents 2-O-acetylated Man, and $\mathrm{Man}_{34}$ represents 3-O-acetylated Man.

\subsection{Histochemical analysis of leaf and stem sections}

Leaf and stem sections were cut using razor blade and examined histochemically. Secondary lignified cell walls were detected using the color reagent of phloroglucinol$\mathrm{HCl}^{47}$ Autofluorescence of the cell walls in UV radiation was examined using sections and isolated cell walls mounted in $\mathrm{H}_{2} \mathrm{O}$ and in $0.1 \mathrm{M}$ ammonium hydroxide. ${ }^{48}$ Starch in cell wall and mucilage preparations was de- tected using potassium iodide, and proteins were detected with Ponceau Red.

\subsection{Isolation of cell-wall alcohol-insoluble residue and mucilage}

The cell-wall preparations were obtained, respectively, from the leaves and stems at $4{ }^{\circ} \mathrm{C}$. The proportion of tissues containing non-lignified primary cell walls was in- 


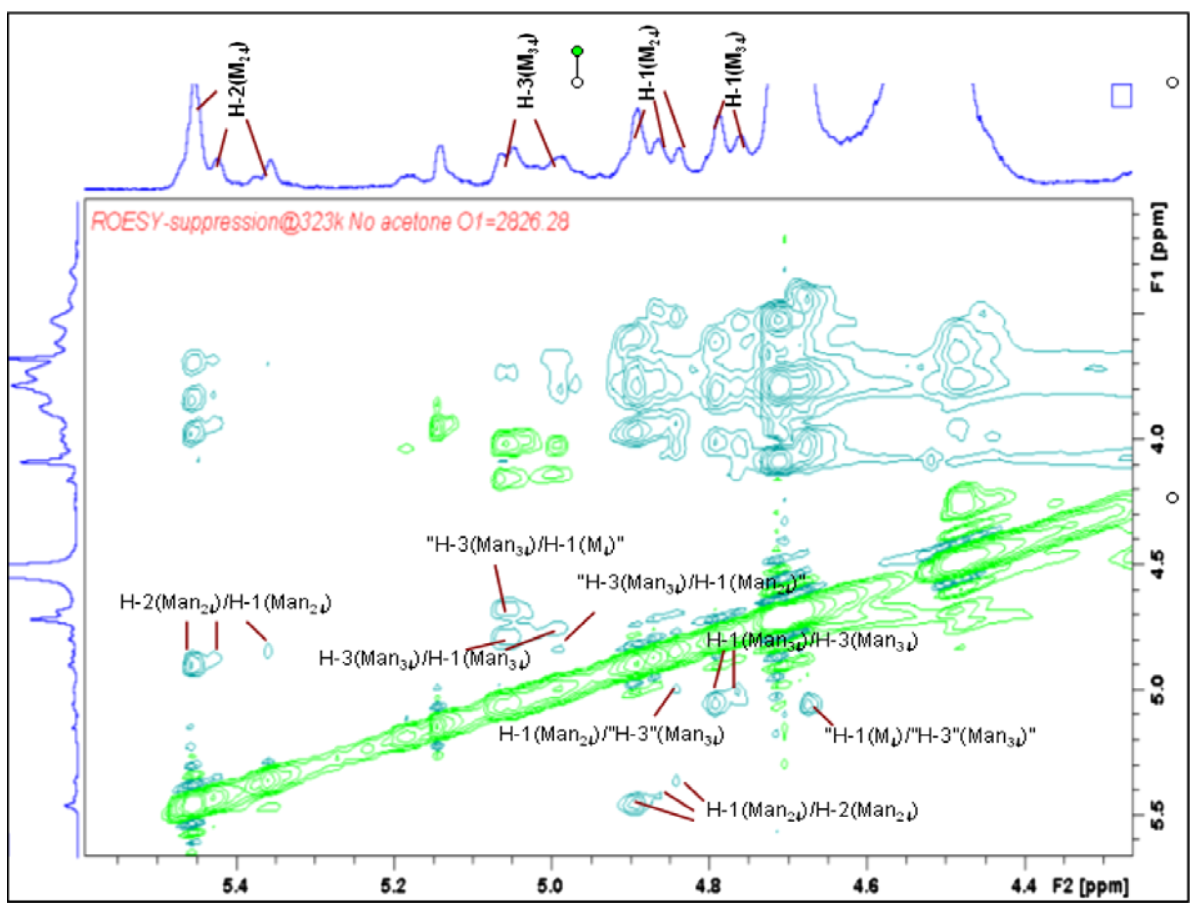

Figure 11. ROESY spectrum of fraction B shows the intra- and inter-glycosidic correlations (indicated by quotation marks) in the glucomannan.

Table 4. ${ }^{1} \mathrm{H}$ and ${ }^{13} \mathrm{C}$ NMR chemical shifts (in $\delta$ values) for the polysaccharide in fraction $\mathrm{B}$

\begin{tabular}{|c|c|c|c|c|c|c|c|c|}
\hline Sugar residues & Linkage & & 1 & 2 & 3 & 4 & 5 & 6 \\
\hline$\rightarrow 4)-\beta-D-G l c-(1 \rightarrow$ & GlcMan & $\begin{array}{l}\delta_{\mathrm{H}} \\
\delta_{\mathrm{C}}\end{array}$ & $\begin{array}{c}4.48 \\
102.8\end{array}$ & $\begin{array}{r}3.32 \\
73.5\end{array}$ & $\begin{array}{c}3.66 \\
74.6\end{array}$ & $\begin{array}{l}3.65 \\
79.2\end{array}$ & $\begin{array}{l}3.50 \\
74.8\end{array}$ & $\begin{array}{l}3.79,3.66 \\
60.6\end{array}$ \\
\hline$\rightarrow 4)-\beta$-D-Man-( $1 \rightarrow$ & ManGlc, ManMan & $\begin{array}{l}\delta_{\mathrm{H}} \\
\delta_{\mathrm{C}}\end{array}$ & $\begin{array}{c}4.71 \\
100.6\end{array}$ & $\begin{array}{l}4.08 \\
70.5\end{array}$ & $\begin{array}{l}3.77 \\
71.9\end{array}$ & $\begin{array}{c}3.79 \\
77.2\end{array}$ & $\begin{array}{l}3.52 \\
75.5\end{array}$ & $\begin{array}{l}3.86,3.72 \\
61.1\end{array}$ \\
\hline$\rightarrow 4)$ - $\beta$-D-Man-( $1 \rightarrow$ & $\operatorname{ManMan}_{34}$ & $\begin{array}{l}\delta_{\mathrm{H}} \\
\delta_{\mathrm{C}}\end{array}$ & $\begin{array}{l}4.68 \\
100.6\end{array}$ & $\begin{array}{l}4.05 \\
70.6\end{array}$ & $\begin{array}{r}3.76 \\
\mathrm{ND}^{\mathrm{a}}\end{array}$ & $\begin{array}{l}3.75 \\
77.7\end{array}$ & $\begin{array}{l}3.44 \\
75.3\end{array}$ & $\begin{array}{l}N^{a} \\
N^{a}\end{array}$ \\
\hline$\rightarrow 4)$-2- $O$-acetyl- $\beta$-D-Man- $(1 \rightarrow$ & $\operatorname{Man}_{24} \operatorname{Man}$ & $\begin{array}{l}\delta_{\mathrm{H}} \\
\delta_{\mathrm{C}}\end{array}$ & $\begin{array}{l}4.89 \\
99.6\end{array}$ & $\begin{array}{c}5.45 \\
72.1\end{array}$ & $\begin{array}{l}3.99 \\
70.6\end{array}$ & $\begin{array}{l}3.83 \\
77.3\end{array}$ & $\begin{array}{c}3.58 \\
76.4\end{array}$ & $\begin{array}{l}3.91 \\
60.4\end{array}$ \\
\hline$\rightarrow 4)$-2- $O$-acetyl- $\beta$-D-Man- $(1 \rightarrow$ & $\operatorname{Man}_{24} \operatorname{Man}_{24}$ & $\begin{array}{l}\delta_{\mathrm{H}} \\
\delta_{\mathrm{C}}\end{array}$ & $\begin{array}{l}4.87 \\
99.4\end{array}$ & $\begin{array}{c}5.42 \\
72.1\end{array}$ & $\begin{array}{l}3.95 \\
70.7\end{array}$ & $\begin{array}{c}3.82 \\
77.9\end{array}$ & $\begin{array}{c}3.48 \\
76.3\end{array}$ & $\begin{array}{l}3.96,3.79 \\
\mathrm{ND}^{\mathrm{a}}\end{array}$ \\
\hline$\rightarrow 4)-2$ - $O$-acetyl- $\beta$-D-Man- $(1 \rightarrow$ & $\operatorname{Man}_{24} \operatorname{Man}_{34}$ & $\begin{array}{l}\delta_{\mathrm{H}} \\
\delta_{\mathrm{C}}\end{array}$ & $\begin{array}{l}4.84 \\
99.2\end{array}$ & $\begin{array}{c}5.36 \\
72.0\end{array}$ & $\begin{array}{c}3.93 \\
70.6\end{array}$ & $\begin{array}{c}3.82 \\
77.2\end{array}$ & $\begin{array}{c}3.50 \\
76.3\end{array}$ & $\begin{array}{l}\mathrm{ND}^{\mathrm{a}} \\
\mathrm{ND}^{\mathrm{a}}\end{array}$ \\
\hline$\rightarrow 4)$-3- $O$-acetyl- $\beta$-D-Man- $(1 \rightarrow$ & $\operatorname{Man}_{34} \operatorname{Man}$ & $\begin{array}{l}\delta_{\mathrm{H}} \\
\delta_{\mathrm{C}}\end{array}$ & $\begin{array}{r}4.79 \\
100.0\end{array}$ & $\begin{array}{l}4.15 \\
69.2\end{array}$ & $\begin{array}{l}5.05 \\
74.0\end{array}$ & $\begin{array}{c}4.00 \\
73.7\end{array}$ & $\begin{array}{c}3.60 \\
75.7\end{array}$ & $\begin{array}{l}N^{a} \\
N^{a}\end{array}$ \\
\hline$\rightarrow 4)$-3- $O$-acetyl- $\beta$-D-Man- $(1 \rightarrow$ & $\operatorname{Man}_{34} \operatorname{Man}_{24}$ & $\begin{array}{l}\delta_{\mathrm{H}} \\
\delta_{\mathrm{C}}\end{array}$ & $\begin{array}{l}4.76 \\
100.2\end{array}$ & $\begin{array}{l}4.14 \\
69.2\end{array}$ & $\begin{array}{l}4.99 \\
74.4\end{array}$ & $\begin{array}{c}4.03 \\
73.7\end{array}$ & $\begin{array}{l}3.55 \\
75.7\end{array}$ & $\begin{array}{l}N^{a} \\
N^{a}\end{array}$ \\
\hline
\end{tabular}

${ }^{\mathrm{a}}$ Not determined.

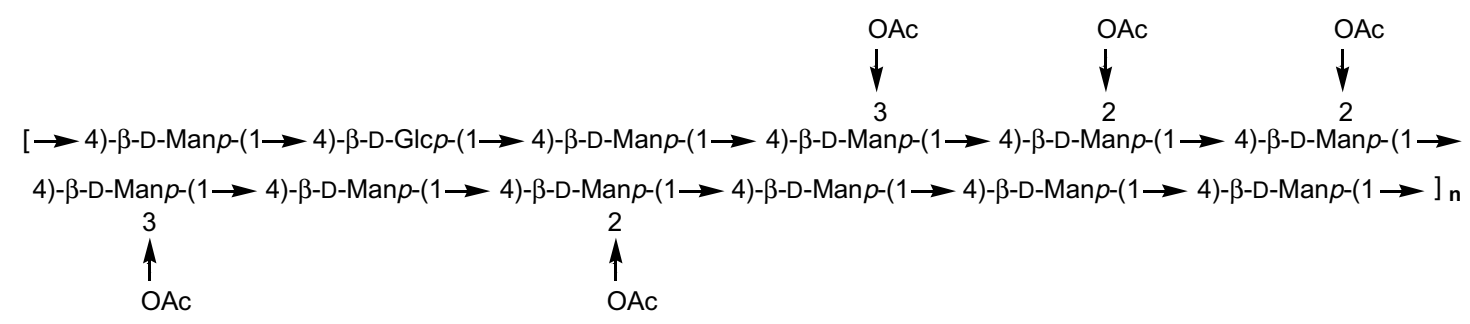

Figure 12. A tentative partial structure of the polysaccharide in fraction B. 
creased by cutting away the tissues that contain lignified secondary cells walls. The collected tissues $(30 \mathrm{~g})$ were homogenized in $50 \mathrm{mM}$ Hepes-KOH buffer ( $\mathrm{pH} 7.2$ ) containing $0.05 \%$ of 2 -mercaptoethanol. The homogenate was filtered through Miracloth, and washed with the same Hepes-KOH buffer. Liquid nitrogen was added and the residue ground to fine powders. Proteins released from cell were visualized by Ponceau 2R. The fine powders were then mixed with ice-cold water, sonicated (1 min), centrifuged, and the supernatant was carefully removed. This procedure was repeated for additional three times. The pellets were recovered by filtration through Miracloth, and thoroughly washed with water and $70 \%$ ethanol until the filtrate becomes clear. Residues were then washed with $100 \%$ ethanol, followed by methanol and $n$-pentane, and dried overnight over silica gel under vacuum.

Mucilage was collected by gently scratching the surface of defrost leaf and stem, then homogenized in 70\% ethanol containing $0.05 \%$ of 2-mercaptoethanol. The homogenate was sonicated $(2 \mathrm{~min})$ and dialyzed against water for $24 \mathrm{~h}$ at $4{ }^{\circ} \mathrm{C}$. Mucopolysaccharides were then recovered by lyophilization. Deacetylation of the mucilage polysaccharides was done by treatment with alkali. The sample was treatment with $1 \mathrm{M} \mathrm{NaOH}$ in the presence of $1 \% \mathrm{NaBH}_{4}$ for $1 \mathrm{~h}$ at ambient temperature to remove acetyl groups, and suspension was then neutralized with glacial acetic acid to $\mathrm{pH}$ 5. Deacetylated mucilage polysaccharides were recovered by dialysis and lyophilization.

\subsection{Removal of contaminating starch}

The dried cell-wall preparation (200 mg) was suspended in $5 \mathrm{mM}$ Tris-maleate buffer $(\mathrm{pH} 6.9)$, and heated $\left(85^{\circ} \mathrm{C}, 5 \mathrm{~min}\right)$ to gelatinize the starch granules. After cooling to $40^{\circ} \mathrm{C}$, porcine pancreatic-amylase $(6300 \mathrm{U}$, Sigma) in $15 \mathrm{mM}$ Tris-maleate buffer (pH 6.9, $25 \mathrm{~mL})$ containing $2 \mathrm{mM} \mathrm{CaCl}_{2}$ was added, and the suspension was incubated for $1 \mathrm{~h}$ at $40{ }^{\circ} \mathrm{C}$. The mixture was centrifuged at $500 \mathrm{~g}$, and the supernatant was removed. The pellets were suspended with $5 \mathrm{mM}$ Tris-maleate, sonicated, filtered onto nylon mesh (pore size $11 \mu \mathrm{m}$ ), and washed with Milli-Q water until filtrate become clear. A small proportion of residue was tested with a drop of KI to indicate the absence of starch. The pellets of cell walls were dried on nylon mesh using solvent exchange by washing with ethanol, methanol, and $n$-pentane.

\subsection{Sequential extraction of cell-wall polymers}

The de-starched cell walls ( $50 \mathrm{mg}$ ) were fractionated by a sequence of extraction using $50 \mathrm{mM}$ CDTA (pH 6.5), $\mathrm{Na}_{2} \mathrm{CO}_{3}+25 \mathrm{mM} \mathrm{NaBH}_{4}, 1 \mathrm{M} \mathrm{KOH}+25 \mathrm{mM}$ $\mathrm{NaBH}_{4}$, and $4 \mathrm{M} \mathrm{KOH}+25 \mathrm{mM} \mathrm{NaBH}_{4}$ as previously described. ${ }^{38}$ The remaining insoluble residue was accounted for the $\alpha$-cellulose fraction.

\subsection{Neutral monosaccharide composition of cell walls and mucilage}

The de-starched cell-wall preparation $(10 \mathrm{mg})$ or individual cell-wall fraction $(5 \mathrm{mg})$ or mucilage preparation
(5 mg) were hydrolyzed, respectively, with $4 \mathrm{M}$ trifluoroacetic acid (TFA) at $121^{\circ} \mathrm{C}$ for $1 \mathrm{~h}$. The mixture was cooled, and TFA was removed under reduced pressure. The acid hydrolysate was washed with 50\% aqueous methanol, and then dried in vacuo. Reduction of monosaccharides in the hydrolysate was carried out by using $\mathrm{NaBH}_{4}(80 \mathrm{mg})$ in $\mathrm{MeOH}$ at room temperature for $30 \mathrm{~min}$. This procedure was repeated for 3-5 times to assure complete reduction of monosaccharides to alditols. The mixture was washed with concentrated $\mathrm{HCl}$ and $\mathrm{MeOH}$, and then dried in vacuo. The reduction product of alditols was subjected to acetylation using acetic anhydride in pyridine $(1: 2)$ at $80^{\circ} \mathrm{C}$ for $2 \mathrm{~h}$, followed by incubation at $25^{\circ} \mathrm{C}$ for $16 \mathrm{~h}$. The alditol peracetates were extracted by chloroform $/ 2 \mathrm{M} \mathrm{HCl} \mathrm{(2:1),} \mathrm{and}$ washed carefully with saturated $\mathrm{NaHCO}_{3}$. After removal of chloroform, the composition of alditol peracetates was determined by GC-MS analysis.

\subsection{Linkage analysis of the cell-wall polysaccharides}

Each cell-wall fraction (10 mg) was dissolved in DMSO $(2 \mathrm{~mL})$, treated with $\mathrm{NaH}$ for 2 min with continuous stirring, and ice-cold MeI ( $1 \mathrm{~mL})$ was added. After stirring at room temperature for $16 \mathrm{~h}$, the methylated polysaccharides in suspension were separated by addition of chloroform/water (2:1). The organic phase was washed with $10 \% \quad \mathrm{Na}_{2} \mathrm{~S}_{2} \mathrm{O}_{3}$ and water, and then concentrated under reduced pressure to give the crude product of methylated polysaccharides. The IR and ${ }^{1} \mathrm{H}$ NMR analyses indicated no presence of hydroxyl group. According to the above-described procedure, the product of methylated polysaccharides was similarly digested with TFA, reduced with $\mathrm{NaBH}_{4}$, and acetylated with $\mathrm{Ac}_{2} \mathrm{O}$ /pyridine to give methylated alditol peracetates. The composition of methylated alditol peracetates was determined by $\mathrm{GC}-\mathrm{MS}$ analysis.

\subsection{Uronic acid composition of cell walls and the cell-wall fractions}

Using $m$-hydroxyl diphenyl as the chromogen, the total content of uronic acids in cell walls and each cell-wall fraction was determined according to the previously reported method. ${ }^{49}$ Galacturonic acid (GalA), glucuronic acid (GlcA), and 4-O-methylglucuronic acid (MeGlcA) in acid hydrolysates were separated and quantified by HPAEC-PAD (Dionex, Sunnyvale, CA, USA) on a CarboPAC-1 column eluted with isocratic gradient of $150 \mathrm{mM} \mathrm{NaOAc}$ containing $100 \mathrm{mM} \mathrm{NaOH}$ at a flow rate of $0.25 \mathrm{~mL} \mathrm{~min}^{-1}$.

\subsection{Enzyme hydrolysis}

The polysaccharide fractions were treated with different enzymes to release oligosaccharides for further analysis. Enzymatic reactions were stopped by boiling for $2 \mathrm{~min}$. The CDTA fractions ( $2 \mathrm{mg}$ ) of leaf and stem wall fractions were treated with polygalacturonase $(50 \mathrm{U})$ from A. niger (EC 3.2.1.15) with $100 \mathrm{mM} \mathrm{NaOAc}$ (pH 4.0, $200 \mu \mathrm{L}$ ) for $16 \mathrm{~h}$ at $50{ }^{\circ} \mathrm{C}$. The $1 \mathrm{M} \mathrm{KOH}$ fractions $(2 \mathrm{mg})$ of leaf and stem wall preparations were treated with endo- $(1 \rightarrow 4)-\beta$-D-xylanase (45 U, EC 3.2.1.8) with 
$100 \mathrm{mM} \mathrm{NaOAc}(\mathrm{pH} 6.0,200 \mu \mathrm{L})$ for $1 \mathrm{~h}$ at $60^{\circ} \mathrm{C}$. The $4 \mathrm{M} \mathrm{KOH}$ fractions $(2 \mathrm{mg}$ ) of leaf and stem wall preparations were treated with endo-( $1 \rightarrow 4)-\beta$-D-glucanase (EC 3.2.1.4, $5 \mathrm{U}$ ) with $50 \mathrm{mM}$ ammonium formate $(\mathrm{pH}$ $5.0,200 \mu \mathrm{L}$ ) for $16 \mathrm{~h}$ at $37^{\circ} \mathrm{C}$. The arabinosyl residues were removed from xylo-oligosaccharides in xylanase digest (1 M KOH fraction of wall preparations) by treatment of $\alpha$-L-arabinosidase from A. niger (EC 3.2.1.55), and endo-( $(\rightarrow 4)-\beta$-D-xylanase digest was freeze dried, redissolved with $100 \mathrm{mM} \mathrm{NaOAc}(\mathrm{pH}$ 6), followed by incubation with $\alpha$-L-arabinosidase $(10 \mathrm{U})$ at $40^{\circ} \mathrm{C}$ for $24 \mathrm{~h}$.

The stem mucilage preparation $(2 \mathrm{mg})$ was treated with endo-( $1 \rightarrow 4)$ - $\beta$-D-mannase (EC 3.2.1.78, $5 \mathrm{U}$ ) with $100 \mathrm{mM} \mathrm{NaOAc}(\mathrm{pH} 4,200 \mu \mathrm{L})$ for $16 \mathrm{~h}$ at $40{ }^{\circ} \mathrm{C}$. The deacetylated glucomannan of fraction $\mathrm{B}$ was digested with endo- $\beta-1,4$-mannase ( $A$. niger, Megazyme) in sodium acetate buffer $(100 \mathrm{mM}, \mathrm{pH} 4.5)$ for $24 \mathrm{~h}$ at $37^{\circ} \mathrm{C}$, using $5 \mu \mathrm{L}$ enzyme per $1 \mathrm{mg}$ of deacetylated glucomannan. Digestion with $\beta$-mannosidase that was specific for $\beta$-1,4-mannosyl linkage ${ }^{38}$ (C. fimi, Megazyme) was conducted in sodium maleate buffer $(100 \mathrm{mM}$, pH 6.5 ) for $24 \mathrm{~h}$ at $37^{\circ} \mathrm{C}$, using $5 \mu \mathrm{L}$ enzyme per $1 \mathrm{mg}$ of deacetylated glucomannan. The attempted digestion with $\alpha$-1,2,3,6-mannosidase (Jack bean, Sigma) was performed in ammonia acetate buffer $(50 \mathrm{mM},+1 \mathrm{mM}$ $\mathrm{ZnCl}_{2}, \mathrm{pH} 5.5$ ) for $24 \mathrm{~h}$ at $37^{\circ} \mathrm{C}$, using $5 \mu \mathrm{L}$ enzyme per $1 \mathrm{mg}$ of deacetylated glucomannan.

\subsection{GC-MS analysis}

The alditol acetates and partially methylated alditol acetates were separated by BPX-70 column (SGE Analytical Science Pty Ltd, Victoria 3134, Australia) on PolarisQ Ion Trap GC-MS/MS System (Thermo Fisher Scientific, Inc., Waltham, MA 024253, USA). Oven temperature was increased from 38 to $150{ }^{\circ} \mathrm{C}$ at $50^{\circ} \mathrm{C} / \mathrm{min}$, then to $230{ }^{\circ} \mathrm{C}$ at $3{ }^{\circ} \mathrm{C} / \mathrm{min}$ and to $260^{\circ} \mathrm{C} / 5 \mathrm{~min}$, with carrier gas $(\mathrm{He})$ at a flow rate of $1 \mathrm{~mL} / \mathrm{min}$. Quantification was done by correcting peak area to mol \%. ${ }^{50}$

\subsection{HPAEC-PAD analysis}

XG oligosaccharides were separated and characterized by HPAEC-PAD with known standards, using a Dionex BioLC system (Dionex, Sunnyvale, CA, USA). A CarboPac PA1 analytical column $(4 \mathrm{~mm} \times 250 \mathrm{~mm})$ and a CarboPac PA1 guard column $(4 \mathrm{~mm} \times 50 \mathrm{~mm})$ were used. The XG oligosaccharides were separated using a linear gradient of $50 \mathrm{mM} \mathrm{NaOAc}+100 \mathrm{mM}$ $\mathrm{NaOH}$ (solvent A) to $100 \mathrm{mM} \mathrm{NaOAc}+100 \mathrm{mM}$ $\mathrm{NaOH}$ (solvent B) at $1 \mathrm{~mL} / \mathrm{min}$ over $110 \mathrm{~min}$. After each run, the column was washed for 10 min with solvent $\mathrm{B}$, 5 min with $300 \mathrm{mM} \mathrm{NaOH}$ (solvent C), and $30 \mathrm{~min}$ with solvent A.

\subsection{Mass spectrometry}

The molecular weights of the sodium adducts of oligosaccharides $[\mathrm{M}+\mathrm{Na}]^{+}$were determined using a BioTOF Ultraflex II (Bruker Daltonics, Billeriaca, MA 01821, USA). The enzyme hydrolysate containing oligosaccha- rides were mixed with $10 \mathrm{mM}$ of 2,5-dihydroxybenzoic acid and $10 \mathrm{mM} \mathrm{NaCl}$ in the ratio of 5:5:3. In MS mode, the spectra were accumulated in average of $2000-3000$ shuts.

\subsection{NMR spectral analysis}

The NMR spectra were recorded on Bruker ADVANCE $600 \mathrm{MHz}$ NMR spectrometer (Bruker BioSpin $\mathrm{GmbH}$, Rheinstetten, Germany) with $5 \mathrm{~mm}$ Cryoprobe DCI ${ }^{1} \mathrm{H} /{ }^{13} \mathrm{C}$. Samples were dissolved in $1 \mathrm{~mL}$ of $\mathrm{D}_{2} \mathrm{O}$. Chemical shifts are given in $\delta$ values relative to HOD signal $\left(\delta_{\mathrm{H}} 4.8\right.$ at $\left.25^{\circ} \mathrm{C}\right)$ or the $\mathrm{H}-1 / \mathrm{C}-1$ signals of mannopyranose $\left(\delta_{\mathrm{H}} 4.71 / \delta_{\mathrm{C}} 100.6\right)$. The HSQC spectra were recorded at $50^{\circ} \mathrm{C}$ to shift the HOD peak about $0.2 \mathrm{ppm}$ upfield, so that the obscured signals in the $(1 \rightarrow 4)$ linked unacetylated $\beta$-Man $p$ residues were revealed. ROESY and TOCSY spectra were recorded, respectively, with mixing times of 100 and $70 \mathrm{~ms}$ as well as the relaxation delays of 3 and $2 \mathrm{~s}$.

\subsection{Determination of molecular weight by DOSY}

The sample of fraction B (1 mg) was dissolved in $400 \mu \mathrm{L}$ of $\mathrm{D}_{2} \mathrm{O}$, and the average molecular weight of the polysaccharide components was determined by DOSY. ${ }^{40}$ The values of hydrodynamic radii were determined from pullulan standards. The DOSY experiment was carried out using a stimulated echo sequence incorporating bipolar sine gradient pulses. In addition, the HOD signal was suppressed by means of presaturation. The gradient strength was logarithmically incremented in 32 steps from $2 \%$ up to $95 \%$ of the maximum gradient strength. The diffusion time was set between 100 and $700 \mathrm{~ms}$. Gradient pulse and longitudinal eddy current were set to 3 and $25 \mathrm{~ms}$, respectively.

\subsection{Preparation of SpMC (murine spleen mononuclear cell)}

Six-to-eight week old male Balb/c were purchased from National Laboratory Animal Center (Taipei, Taiwan) and were sacrificed by cervical dissociation. Mice splenocytes were obtained by pressing spleens through a sterilized stainless steel mesh (100 mesh) and washing the passed suspension three times with HBSS (Gibco) after depleting erythrocytes with red blood cell lysis buffer (Sigma). Finally, the viable cells were counted with a hemocytometer using trypan blue dye exclusion. Singlecell suspensions $\left(5 \times 10^{6}\right.$ cells $\left./ \mathrm{mL}\right)$ were cultured in $10 \%$ RPMI-1640 in a humidified $5 \% \mathrm{CO}_{2}$ incubator at $37^{\circ} \mathrm{C}$.

\subsection{Cytotoxicity/proliferation assay}

Mice splenocytes $\left(5 \times 10^{5}\right.$ cells/well $)$ were stimulated directly with Con A ( $2 \mu \mathrm{g} / \mathrm{mL})$, commercial mannan analogs (konjac glucomannan and ivory nut mannan) or different polysaccharide fractions $(50 \mu \mathrm{g} / \mathrm{mL}$ in water) in 96-well tissue culture plates for $60 \mathrm{~h}$. Afterwards, the cell proliferation was examined with MTS assay using Celltiter $96^{\circledR}$ aqueous one solution cell proliferation assay kit (Promega, Madison, WI) following the manufacturer's instructions. Briefly, $20 \mu \mathrm{L}$ of MTS solu- 
tion was added to each well. After $4 \mathrm{~h}$ incubation at $37^{\circ} \mathrm{C}$, the absorbance at $490 \mathrm{~nm}$ was obtained using a plate reader (SpectraMax M2, Molecular Device, Sunnyvale, CA). The optical density at $490 \mathrm{~nm}\left(\mathrm{OD}_{490}\right)$ for control cells was defined as $100 \%$. Polysaccharide preparation is screened routinely with LAL test (Pyrochrome $^{\circledR}$ Kit, Cape Cod Associates, Falmouth, MA) to ensure no endotoxin contamination. The endotoxin potency $(\mathrm{EU} / \mathrm{mg})$ of each polysaccharide fraction ( $\leqslant$ $1 \times 10 \mathrm{EU} / \mathrm{mg}$ ) was shown in much lower level than that of cell culture with lipopolysaccharide (LPS $\geqslant$ $\left.1 \times 10^{5} \mathrm{EU} / \mathrm{mg}\right)$.

\subsection{Cytokine determination by ELISA}

The concentrations of IL-1 $\alpha$, IL-6, IL-10, IFN- $\gamma$, GCSF, and GM-CSF in the cell culture supernatants were assayed using the Quantikine mouse ELISA kits (R\&D Systems, Minneapolis, MN) according to the manufacturer's protocol. Mice splenocytes $\left(5 \times 10^{6}\right.$ cells/well $)$ were cultured in the presence of mannan, glucomannan, or different polysaccharide fractions at concentration of $50 \mu \mathrm{g} / \mathrm{mL}$ in $24-w e l l$ tissue culture plates. Con A at a final concentration of $2 \mu \mathrm{g} / \mathrm{mL}$ was as used a positive control. After $48 \mathrm{~h}$ following stimulation, culture supernatants were collected and stored at $-80{ }^{\circ} \mathrm{C}$ until ELISA analysis. In this study, all the data points are average from three independent experiments and the represented values are average \pm standard deviation.

\subsection{Cytokine expression inferred from the RNA analysis}

Splenocytes were removed from BALB/c mice (male, 68 weeks) and treated with fractions $\mathrm{A}-\mathrm{F}(100 \mu \mathrm{g} / \mathrm{mL}$ each) for $12 \mathrm{~h}$. Both the cell pellets and supernatants were collected at the end of the incubation period. RNA was extracted from cell pellets and converted to cDNA. Products from PCR were analyzed by gel electrophoresis on $2 \%$ gel to visualize the expressed cytokines.

\section{Acknowledgments}

We thank Yuen-Foong-Yu Co., Ltd for financial support, Dr. Kay-Hooi Khoo (Institute of Biological Chemistry, Academia Sinica) for advice on mass spectrometry, and Dr. Philip Harris (University of Auckland, New Zealand) for the technical advice on GC-MS and microscopy.

\section{References and notes}

1. Chen, X. M.; Guo, S. X. Nat. Prod. Res. Dev. 2001, 13, 70-75.

2. Wrigley, T. C. Nature 1960, 188, 1108.

3. Kierkegaard, P.; Pilotti, A. Acta Chem. Scand. 1970, 24, 3757-3759.

4. Wang, H.; Zhao, T. J. Nat. Prod. 1985, 48, 796-801.

5. Lee, Y. H.; Park, J. D.; Baek, N. I.; Kim, S. I.; Ahn, B. Z. Planta Med. 1995, 61, 178-180.

6. Honda, C.; Yamaki, M. Phytochemistry 2000, 53, 987990.
7. Morita, H.; Fujiwara, M.; Yoshida, N.; Kobayashi, J. Tetrahedron 2000, 56, 5801-5805.

8. Fan, C.; Wang, W.; Wang, Y.; Qin, G.; Zhao, W. Phytochemistry 2001, 57, 1255-1258.

9. Zhao, W.; Ye, Q.; Tan, X.; Jiang, H.; Li, X.; Chen, K.; Kinghorn, A. D. J. Nat. Prod. 2001, 64, 1196-1200.

10. Ye, Q.; Qin, G.; Zhao, W. Phytochemistry 2002, 61, 885-890.

11. Ye, Q.; Zhao, W. Planta Med. 2002, 68, 723-729.

12. Yang, H.; Chou, G.-X.; Wang, Z.-T.; Guo, Y.-W.; Hu, Z.-B.; Xu, L.-S. Helv. Chim. Acta 2004, 87, 395-399.

13. Yang, L.; Wang, Z.; Xua, L. J. Chromatogr., A 2006, $1104,230-237$.

14. Zha, X. Q.; Luo, J. P.; Luo, S. Z.; Kiang, S. T. Carbohydr. Polym. 2007, 69, 86-93.

15. Paulsen, B. S. Curr. Org. Chem. 2001, 5, 939-950.

16. Kierkegaard, P.; Pilotti, A. Acta Chem. Scand. 1970, 24, 379-387.

17. Huang, H. Q.; Cai, T. Y.; Liu, Q. L. Nat. Prod. Res. Dev. 1996, 8, 39-41.

18. Wang, L.-H., Dendrobium plant YFY-HS1, U.S. PP16,746 P3, 2006.

19. S. C. Fry. The Growing of Plant Cell Wall: Chemical and Metabolic Analysis; Longman: Harlow, UK, 1998.

20. Bacic, A.; Harris, P.; Stone, B. Structure and Function of Plant Cell Walls; Academic Press: San Diego, CA, 1988.

21. Zablackis, E.; Huang, J.; Müllerz, B.; Darvill, A. C.; Albersheim, P. Plant Physiol. 1995, 107, 1129-1138.

22. Mercê, A.; Fernandes, E.; Mangrich, A.; Sierakowski, M. J. Braz. Chem. Soc. 2000, 3, 224-231.

23. Prosksch, A.; Wagner, H. Phytochemistry 1987, 26, 1989-1993.

24. Carpita, N. Phytochemistry 1984, 23, 1089-1093.

25. Carpita, N.; Gibeaut, D. Plant J. 1993, 3, 1-30.

26. Smith, B.; Harris, P. Plant Physiol. 1995, 107, 1399-1409.

27. Smith, B.; Harris, P. Phytochemistry 2001, 56, 513-519.

28. McNeil, M.; Darvill, A. G.; Fry, S. C.; Albersheim, P. Ann. Rev. Biochem. 1984, 53, 625-663.

29. Kiyohara, H.; Cyong, J.; Yamada, H. Carbohydr. Res. 1988, 182, 259-275.

30. Samuelsen, A. B.; Paulsen, B.; Wold, J.; Otsuka, H.; Kiyohara, H.; Yamada, H.; Knutsenc, S. Carbohydr. Polym. 1996, 30, 37-44.

31. Zhu, Y.; Pettolino, F.; Mau, S.-L.; Bacic, A. Phytochemistry 2005, 66, 1067-1076.

32. Bui, A.; Bacic, A.; Pettolino, F. Phytochemistry 2006, 67, 1271-1275.

33. Cozzolino, R.; Malvagna, P.; Spina, E.; Giori, A.; Fuzzati, N.; Anelli, A.; Garozzo, D.; Impallomeni, G. Carbohydr. Polym. 2006, 65, 263-272.

34. Kato, Y.; Ito, S.; Mitsuishi, Y. Trends Glycosci. Glycotech. 2004, 16, 393-406.

35. Fry, S. C.; York, W. S.; Albersheim, P.; Darvill, A.; Hayashi, T.; Joseleau, J. P.; Kato, Y.; Lorences, E. P.; Marclachlan, G. A.; McNeil, M.; Mort, A. J.; Reid, J. S. G.; Seit, H. U.; Selvendran, R. R.; Voragen, R. R.; White, A. R. Physiol. Plant. 1993, 89, 1-3.

36. Kato, Y.; Uchida, J.; Ito, S.; Mitsuishi, Y. Int. Congress Ser. 2001, 1223, 161-164.

37. Hua, Y.-F.; Zhang, M.; Fu, C.-X.; Chen, Z.-H.; Chan, G. Y. Carbohydr. Res. 2004, 339, 2219-2224.

38. Chaplin, M. F.; Kennedy, J. F. Carbohydrate Analysis: A Practical Approach; Oxford University Press: Oxford, 1994, pp 247-256.

39. Talmadge, J.; Chavez, J.; Jacobs, L.; Munger, C.; Chinnah, T.; Chow, J. T.; Williamson, D.; Yates, K. Int. Immunopharmacol. 2004, 4, 1757-1773.

40. Viel, S.; Capitani, D.; Mannina, L.; Segre, L. Biomacromolecules 2003, 4, 1843-1847.

41. Suárez, E. R.; Syvitski, R.; Kralovec, J. A.; Noseda, M. D.; Barrow, C. J.; Ewart, H. S.; Lumsden, M. 
D.; Grindley, T. B. Biomacromolecules 2006, 7, 23682376.

42. Prieto, A.; Leal, J. A.; Giménez-Abián, M. I.; Canales, Á.; Jiménez-Barbero, J.; Bernabé, M. Glycoconjugate J. 2007, 24, 421-428.

43. Agrawal, P. K. Phytochemistry 1992, 31, 3307-3330.

44. Capek, P.; Alföldi, J.; Lišková, D. Carbohydr. Res. 2002, 337, 1033-1037.

45. Hannuksela, T.; Penhoat, C. H. Carbohydr. Res. 2004, 339, 301-312.
46. For the details of glucomannan assay kit, see: http://secure.megazyme.com/downloads/en/data/K-GLUM. pdf.

47. Harris, P.; Webster, J.; Weinhandl, J. A.; Stone, B. A. Sex. Plant Reprod. 1994, 7, 101-106.

48. Harris, P.; Hartley, R. Nature 1976, 259, 508-510.

49. Blumenkrantz, N.; Asboe-Hansen, G. Anal. Chem. 1973, 54, 484-489.

50. Sweet, D.; Sharpiro, R.; Albersheim, P. Carbohydr. Res. 1975, 40, 217-225. 